\title{
Nanomaterial-Based Fluorescence Resonance Energy Transfer (FRET) and Metal-Enhanced Fluorescence (MEF) to Detect Nucleic Acid in Cancer Diagnosis
}

\author{
Jin-Ha Choi ${ }^{1,+} \mathbb{\infty}$, Taehyeong Ha ${ }^{2,+} \mathbb{C}$, Minkyu Shin ${ }^{2}$, Sang-Nam Lee ${ }^{3, *}$ and Jeong-Woo Choi ${ }^{2, *}$ \\ 1 School of Chemical Engineering, Jeonbuk National University, Jeonju 54896, Korea; jhchoi@jbnu.ac.kr \\ 2 Department of Chemical and Biomolecular Engineering, Sogang University, Seoul 04107, Korea; \\ hatae91@sogang.ac.kr (T.H.); mkshin91@sogang.ac.kr (M.S.) \\ 3 Uniance Gene Inc., 1107 Teilhard Hall, 35 Baekbeom-Ro, Mapo-Gu, Seoul 04107, Korea \\ * Correspondence: snlee9191@hanmail.net (S.-N.L.); jwchoi@sogang.ac.kr (J.-W.C.); \\ Tel.: +82-2-705-8480 (J.-W.C.); Fax: +82-2-718-1976 (J.-W.C.) \\ + These authors contributed equally to this work.
}

check for updates

Citation: Choi, J.-H.; Ha, T.; Shin, M.; Lee, S.-N.; Choi, J.-W.

Nanomaterial-Based Fluorescence

Resonance Energy Transfer (FRET) and Metal-Enhanced Fluorescence (MEF) to Detect Nucleic Acid in Cancer Diagnosis. Biomedicines 2021, 9, 928. https://doi.org/10.3390/ biomedicines 9080928

Academic Editor: Natalia Komarova

Received: 29 June 2021

Accepted: 28 July 2021

Published: 31 July 2021

Publisher's Note: MDPI stays neutral with regard to jurisdictional claims in published maps and institutional affiliations.

Copyright: (c) 2021 by the authors. Licensee MDPI, Basel, Switzerland. This article is an open access article distributed under the terms and conditions of the Creative Commons Attribution (CC BY) license (https:/ / creativecommons.org/licenses/by/ $4.0 /)$.

\begin{abstract}
Nucleic acids, including DNA and RNA, have received prodigious attention as potential biomarkers for precise and early diagnosis of cancers. However, due to their small quantity and instability in body fluids, precise and sensitive detection is highly important. Taking advantage of the ease-to-functionality and plasmonic effect of nanomaterials, fluorescence resonance energy transfer (FRET) and metal-enhanced fluorescence (MEF)-based biosensors have been developed for accurate and sensitive quantitation of cancer-related nucleic acids. This review summarizes the recent strategies and advances in recently developed nanomaterial-based FRET and MEF for biosensors for the detection of nucleic acids in cancer diagnosis. Challenges and opportunities in this field are also discussed. We anticipate that the FRET and MEF-based biosensors discussed in this review will provide valuable information for the sensitive detection of nucleic acids and early diagnosis of cancers.
\end{abstract}

Keywords: fluorescence resonance energy transfer; metal-enhanced fluorescence; nucleic acid; cancer; nanoparticle

\section{Introduction}

Cancer is one of the dominant and highly influential diseases in human life. Even though the five-year survival rates have gradually increased, the death rate is still above $0.1 \%$, and the cancer incidence is approximately $0.4 \%[1,2]$. In addition, cancer has become more frequent due to the increasing lifespan. For effective treatment, and to increase the cure rate of cancers, it is crucial to diagnose the exact types and stages precisely and sensitively. For example, some anticancer drugs are effective only against a certain type of cancer [3]. However, early diagnosis of cancers makes a recovery easier than late diagnosis due to the severe progression and metastasis of cancers $[4,5]$. Therefore, it is essential to develop a precise and sensitive diagnostic strategy that can detect and identify cancer tissue at the early stage and analyze its characteristics for the appropriate therapy.

As cancer develops, several biological changes, such as cellular levels of DNA, RNA, protein, and other small molecules, occur in body fluids [6-9]. Thus, quantitation of these molecules can be used as an essential parameter for cancer diagnosis. Among them, nucleic acids have been used as potential biomarkers due to their differential levels between cancer patients and healthy individuals $[10,11]$. Compared with other biomarkers, nucleic acids have the benefit and potential of serving as relatively stable biomarkers in body fluids for cancer diagnosis. However, nucleic acids have some limitations as potential biomarkers. A major challenge of using them is the low concentration of target sequences in the presence of high noise factors, such as non-target biomolecules and serum [12-15]. Therefore, several 
precise and sensitive detection methods have been developed to overcome these conditions. Among these detection methods, a fluorescent signal is an excellent and widely used technique for recognizing nucleic acids [16-19].

The fluorescence-based analytical methods provide precise, sensitive, and reproducible quantification of cancer-related biomarkers as well as nucleic acids. In addition, changes in the fluorescent signals by the biological event, such as DNA hybridization, can be easily observed. Based on these advantages, fluorescence-based detection methods have been widely utilized in typical biological experiments, including immunostaining and polymerase chain reaction (PCR). Over the past decades, fluorescence-based systems have been improved by integrating several nanomaterials, which translate the recognition of the interaction into the changes in fluorescence wavelength and intensity, such as fluorescence resonance energy transfer (FRET) and metal-enhanced fluorescence (MEF) effects, making these systems excellent platforms for nucleic acid-sensing for cancer diagnosis [19-23]. In this review, we describe the current state-of-the-art developments in nanomaterial-based fluorescent biosensors, with a focus on FRET and MEF, for quantification of diverse nucleic acids, including DNA and RNA, to diagnose cancers precisely and sensitively. We believe that the topics described and discussed in this review can provide practical information and a brief insight into the current status and prospect of developing a nanotechnology-based fluorescent nucleic acid-sensing system for biomedical applications.

\section{Nucleic Acid Targets}

\subsection{Genomic DNA ( $g D N A)$}

gDNA refers to the cellular DNA component that houses the biological information of the cell and can be passed on to the next generation. The genomic analysis provides information about the structural and molecular changes in DNA as well as the changes in gene expression. Analysis of the epigenetic changes in DNA can help identify new drug targets for cancer diagnosis and treatment [24]. Among the reported drug targets, 5-hydroxymethylcytosine (5-hmc) is downregulated in several types of cancer cells. This observation indicates that changes in the cellular level of 5-hmC can be used for cancer diagnosis. Therefore, high-performance liquid chromatography (HPLC) [25], fluorescence [26], electrochemistry [27,28], and electrochemiluminescence (ECL) [29] methods have been developed for cancer diagnosis.

\subsection{Other DNAs}

Cell-free DNA (cfDNA) refers to any DNA outside a cell. DNA methylation is an important epigenetic modification strongly implicated in the physiological regulation of gene expression. The DNA methylation patterns in cancer tissues differ from those in healthy tissues, irrespective of the tissue origin of cancer cells. This difference enables distinguishing cancer tissues from healthy tissues. In addition, DNA methylation patterns can be utilized for early cancer diagnosis, cancer-specific genetic testing, and cancer treatment [30-32]. The cfDNA in the bloodstream is in part caused by tumor-specific mutations, and this cfDNA sub-population is called circulating tumor DNA (ctDNA). Because ctDNA is present in the bloodstream, it is a potentially important biomarker for the early detection of cancer. However, the concentration of ctDNA in the bloodstream of a cancer patient is incredibly low, hampering a quick and accurate diagnosis of cancer. Therefore, studies on fast-responsive and ultrasensitive biosensors have been undertaken [33,34].

\subsection{Messenger RNA (mRNA)}

mRNA is a single-stranded molecule of RNA that is complementary to the genetic sequence of a gene and has been commonly used as a biomarker for early detection and treatment of cancer due to its humoral stability and biological regulatory function. It is usually quantitatively detected using quantitative reverse transcription-polymerase chain reaction (qRT-PCR) [35-37]. Although qRT-PCR is a very sensitive method, it is timeconsuming and requires heavy instruments for the associated thermocycling reactions. 
Therefore, isothermal gene amplification [36,38], ECL [39], fluorescence [40,41], electrochemistry [42,43], and surface plasmon resonance (SPR) [44] have been developed as an alternative to PCR for mRNA detection.

\subsection{Non-Coding RNA (ncRNA)}

An ncRNA is a functional RNA molecule that is not translated into a protein. These RNAs can be classified as small RNAs (sRNAs) (19-31 nucleotides) or long ncRNAs (>200 nucleotides) [45]. MicroRNAs (miRNAs) of the sRNA families are known to be directly involved in gene expression. The expression of various miRNAs is dysregulated in human cancers through a variety of mechanisms [46,47]. Among such miRNAs, miRNA-21 is upregulated in colorectal cancer and induces cellular invasion, apoptosis, and drug resistance [48]. In addition, miRNA-203 has been observed to promote the carcinogenic transformation of cells and cancer cell proliferation. This miRNA is upregulated in breast cancer [49], whereas miRNA-330 is downregulated in prostate cancer and lung cancer cells [50]. Various miRNA detection platforms based on fluorescence [51], electrochemistry [52], ECL [53], or SPR [54] have been developed.

\section{FRET-Based Nucleic Acid Biosensors for Cancer Diagnosis}

\subsection{FRET}

FRET is a distance-dependent energy transfer process between two fluorophores, one of which acts as an energy donor fluorophore and the other as an acceptor. Thus, FRET can be used to measure the nanoscale distance between two interacting biomolecules (Figure 1a) [55-58]. The proximity between the donor and acceptor should be $<10 \mathrm{~nm}$, and for such a single fluorophore pair, the efficiency of FRET is inversely proportional to the sixth power of the distance between the donor and acceptor, so FRET changes the distance between donor and acceptor. This highly sensitive technique has been widely used as a powerful tool to study the intermolecular distance between fluorophores and molecular conformational changes [59-61]. Based on this principle, FRET is used for the detection and quantification of nucleic acids and proteins extracted from blood. However, because the concentrations of nucleic acids, including RNA and DNA, in the blood of cancer patients are extremely low, an ultrasensitive and accurate detection method is required. The integration of nanomaterials for ultrasensitivity and high specificity has improved FRET performance in the detection of DNA and RNA molecules. There are many studies on FRET-based nanobiosensors for nucleic acid detection (Table 1). 


\section{a FRET}
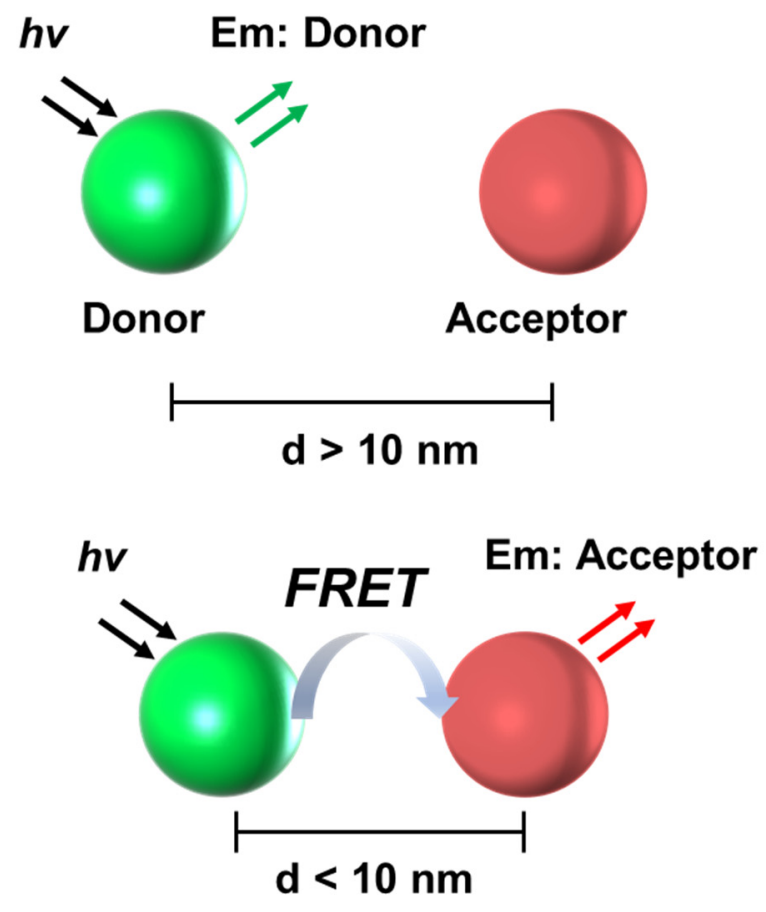

\section{b MEF}

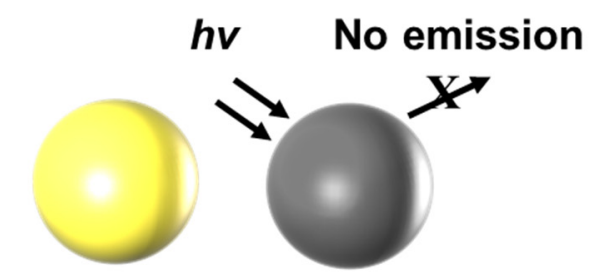

Metal NPs Fluorophore
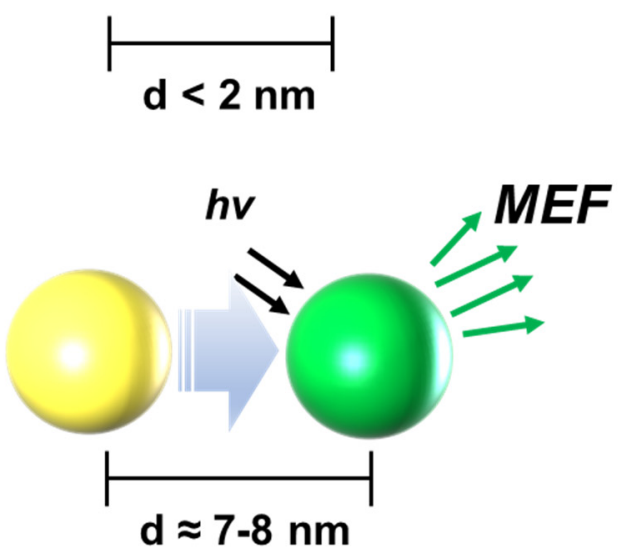

Figure 1. The simple mechanism of the (a) FRET and (b) MEF phenomena. FRET is induced when the distance between donor and acceptor is $<10 \mathrm{~nm}$. In the case of MEF, metal NPs can enhance the fluorescence intensity of fluorophore when the distance is around 7 8 $\mathrm{nm}$.

Table 1. Comparison of FRET-based nanobiosensors for nucleic acid detection.

\begin{tabular}{|c|c|c|c|c|c|c|}
\hline Feature & Donor/Acceptor & $\begin{array}{l}\text { Wavelengths } \\
(\text { Ex,Em) }\end{array}$ & Target & $\begin{array}{c}\text { Required } \\
\text { Time }\end{array}$ & $\begin{array}{l}\text { Detection } \\
\text { Limit }\end{array}$ & Ref \\
\hline $\begin{array}{l}\text { FAM-labeled DNA probe } \\
\text { adsorption on AuNPs via } \\
\text { thiol-modified probes; When } \\
\text { hybridizing with target DNA, } \\
\text { fluorescence occurrence due to } \\
\text { reduced interaction and increased } \\
\text { distance. }\end{array}$ & $\begin{array}{l}\text { AuNPs/FAM- } \\
\text { labeled DNA } \\
\text { probe }\end{array}$ & $\begin{array}{l}\text { Ex: } 545 \mathrm{~nm} \\
\text { Em: } 580 \mathrm{~nm}\end{array}$ & $\begin{array}{c}\text { methylated } \\
\text { DNA }\end{array}$ & $>2 \mathrm{~h}$ & $2.2 \mathrm{pM}$ & [62] \\
\hline $\begin{array}{l}\text { Aggregation-induced release (AIE) } \\
\text { molecules and cDNA adsorption on } \\
\text { GO via } \pi-\pi \text { stacking; Increased } \\
\text { distance by reduced interaction } \\
\text { when hybridizing with target DNA } \\
\text { eliminates quenching effect }\end{array}$ & $\begin{array}{l}\text { GO/AIE } \\
\text { labeled DNA } \\
\text { probe }\end{array}$ & $\begin{array}{l}\text { Ex: } 370 \mathrm{~nm} \\
\text { Em: } 465 \mathrm{~nm}\end{array}$ & DNA & $3 \mathrm{~min}$ & $3.1 \mathrm{pM}$ & [63] \\
\hline $\begin{array}{l}\text { FAM-labeled DNA adsorption on } \\
\text { GO via } \pi-\pi \text { stacking; FAM-labeled } \\
\text { ssDNA desorption and fluorescence } \\
\text { recovery from GO through addition } \\
\text { of target DNA }\end{array}$ & $\begin{array}{l}\text { GO/FAM- } \\
\text { labeled DNA } \\
\text { probe }\end{array}$ & $\begin{array}{l}\text { Ex: } 488 \mathrm{~nm} \\
\text { Em: } 520 \mathrm{~nm}\end{array}$ & $\begin{array}{c}\text { Exon } 10 \\
\text { (EGFR gene) }\end{array}$ & $10 \mathrm{~min}$ & $35 \mathrm{fmol} / \mu \mathrm{L}$ & {$[64]$} \\
\hline $\begin{array}{l}\text { FAM-labeled DNA adsorption on } \\
\mathrm{Ti}_{3} \mathrm{C}_{2} \text { NSs via } \pi-\pi \text { stacking; } \\
\text { Detection of PCR-amplified HPV-18 } \\
\text { DNA from cervical scrape samples }\end{array}$ & $\begin{array}{l}\mathrm{Ti}_{3} \mathrm{C}_{2} \\
\text { NSs/FAM- } \\
\text { DNA } \\
\text { probe }\end{array}$ & $\begin{array}{l}\text { Ex: } 495 \mathrm{~nm} \\
\text { Em: } 520 \mathrm{~nm}\end{array}$ & HPV-18 & $5 \mathrm{~min}$ & $100 \mathrm{pM}$ & [65] \\
\hline
\end{tabular}


Table 1. Cont.

\begin{tabular}{|c|c|c|c|c|c|c|}
\hline Feature & Donor/Acceptor & $\begin{array}{l}\text { Wavelengths } \\
\text { (Ex,Em) }\end{array}$ & Target & $\begin{array}{l}\text { Required } \\
\text { Time }\end{array}$ & $\begin{array}{l}\text { Detection } \\
\text { Limit }\end{array}$ & Ref \\
\hline $\begin{array}{l}\text { Target DNA detection by Rho } 110 \\
\text { and 6G-PMMA using a smartphone } \\
\text { RGB camera using a two-color } \\
\text { fluorescence microscope; Prevention } \\
\text { dye self-quenching of polymer } \\
\text { nanoparticles encapsulating green } \\
\text { fluorescent donor (Rho } 110 \text { and 6G) } \\
\text { and hydrophobic counterions } \\
\text { (ATTO647N) as acceptors }\end{array}$ & $\begin{array}{l}\text { Rho } 110 / 6 \mathrm{G}- \\
\text { PMMA/ } \\
\text { ATTO647N }\end{array}$ & $\begin{array}{l}\text { Ex: } 488 \mathrm{~nm} \\
\text { Em: } 662 \mathrm{~nm}\end{array}$ & DNA & $3 \mathrm{~h}$ & $10 \mathrm{fM}$ & [66] \\
\hline $\begin{array}{c}\text { Covalent binding of } \\
\text { TAMRA-labeled MUC1 aptamer } \\
\text { and TAMRA-labeled miR-21 to the } \\
\text { surface of chimeric } \\
\text { DNA-functionalized } \mathrm{Ti}_{3} \mathrm{C}_{2} ; \text { Red and } \\
\text { green fluorescence recovery by } \\
\text { nanoprobe and target MUC1, } \\
\text { miR-21 hybridization. }\end{array}$ & $\begin{array}{c}\text { Functionalized } \\
\mathrm{Ti}_{3} \mathrm{C}_{2} / \text { TAMRA- } \\
\text { miR-21, } \\
\text { TAMRA-MUC1 }\end{array}$ & $\begin{array}{l}\text { Ex: } 488 \mathrm{~nm} \\
\text { Em: } 525 \mathrm{~nm}\end{array}$ & $\begin{array}{l}\text { miR-21 } \\
\text { MUC1 }\end{array}$ & $2 \mathrm{~h}$ & $0.8 \mathrm{nM}$ & [67] \\
\hline $\begin{array}{l}\text { Isolation and green fluorescence } \\
\text { recovery of dye-labeled ssDNA on } \\
\text { the surface of } \mathrm{MoS}_{2} \text { nanosheets due } \\
\text { to hybridization between the probe } \\
\text { and the target miR. }\end{array}$ & $\begin{array}{l}\mathrm{MoS}_{2} / \mathrm{FAM}- \\
\text { miR } 21 \\
\text { probe }\end{array}$ & $\begin{array}{l}\text { Ex: } 488 \mathrm{~nm} \\
\text { Em: } 520 \mathrm{~nm}\end{array}$ & $\operatorname{miR}-21$ & $>2 \mathrm{~h}$ & $10-50 \mathrm{nM}$ & [68] \\
\hline $\begin{array}{c}\text { Detection of UV-vis and gel } \\
\text { electrophoresis from 1-aptamers } \\
\text { attached to the probe surface using } \\
\text { high surface area MOFs. }\end{array}$ & $\begin{array}{c}\mathrm{La}(\mathrm{III}) \\
\mathrm{MOFs} / \mathrm{AgNPs}\end{array}$ & $\begin{array}{l}\text { Ex: } 220 \mathrm{~nm} \\
\text { Em: } 430 \mathrm{~nm}\end{array}$ & $\operatorname{miR}-155$ & $45 \mathrm{~min}$ & $5.5 \mathrm{fM}$ & [69] \\
\hline $\begin{array}{l}\text { FAM-labeled DNA adsorption on } \\
\text { GO via } \pi-\pi \text { stacking; Collection and } \\
\text { detection of DNA-miR complexes } \\
\text { after the target miRNA } \\
\text { hybridization with the probe and } \\
\text { detaches from the reaction channel. }\end{array}$ & $\begin{array}{l}\text { GO/FAM- } \\
\text { labeled DNA } \\
\text { probes }\end{array}$ & $\begin{array}{l}\text { Ex: } 488 \mathrm{~nm} \\
\text { Em: } 520 \mathrm{~nm}\end{array}$ & $\begin{array}{l}\text { miR-125, } \\
\text { miR-126, } \\
\text { miR-191, } \\
\text { miR-155, } \\
\text { miR-21, }\end{array}$ & $35 \mathrm{~min}$ & $0.146 \mathrm{aM}$ & [70] \\
\hline
\end{tabular}

\subsection{FRET-Based Biosensors for Detection of DNA Targets}

DNA detection at single-molecule sensitivity is the ultimate goal in biosensing and cancer diagnosis. Among the many techniques proposed for DNA detection, nanotechnology has shown great potential. Two dimensional (2D) nanomaterials with outstanding electronic and optical properties, such as broad absorbance, large surface area, and easily functionalized surface sites, can be utilized as acceptors or quenchers in FRET sensors [62,71,72]. To date, various nanomaterials, such as Au nanoparticles (NPs) [62], $\mathrm{MoS}_{2}$ [73], graphene oxide (GO) [63,64], and MXenes [66], have been developed for the fluorescence detection of DNA for cancer diagnoses. Eftekhari-Sis et al. developed a nanobiosensor based on graphene oxide (GO) and 5-carboxy fluorescein (FAM)-labeled DNA for the detection of a deletion mutation in exon 19 of the EGFR gene (Figure 2a) [65]. This system can detect a target DNA in a small amount of sample solution in 10 min with a very low detection limit of $25 \mathrm{fmol} / \mu \mathrm{L}$. Dhenadhayalan et al. reported an ultrasensitive system based on molybdenum series $\left(\mathrm{MoO}_{3}, \mathrm{MoS}_{2}\right.$, and $\left.\mathrm{MoSe}_{2}\right)$ of $2 \mathrm{D}$ nanosheets (NSs) for the detection of a prostate-specific antigen (PSA) as a diagnostic biomarker of prostate cancer [63]. The detection was achieved with 13 pM of $\mathrm{MoO}_{3} \mathrm{NSs}$, whereas $\mathrm{MoS}_{2}$ and $\mathrm{MoSe}_{2}$ NSs showed detection limits of 72 and 157 pM, respectively, among which the $\mathrm{MoO}_{3}$ sensor system showed a fast fluorescence response within $2 \mathrm{~min}$. Severi et al. developed a FRET-based DNA nanoprobe for detecting DNA by using a smartphone camera [66]. 
The green-emitting NPs are based on rhodamine 110, and the 6G dye is paired with a massive hydrophobic counterion, which is a DNA cancer marker targeting polymer NPs functionalized with red-emitting oligonucleotides and the FRET receptor ATTO647N (survivin) (Figure 2b,c). Using a smartphone, survivin detection can easily detect nanoprobe responses at the $10 \mathrm{pM}$ detection limits.

a

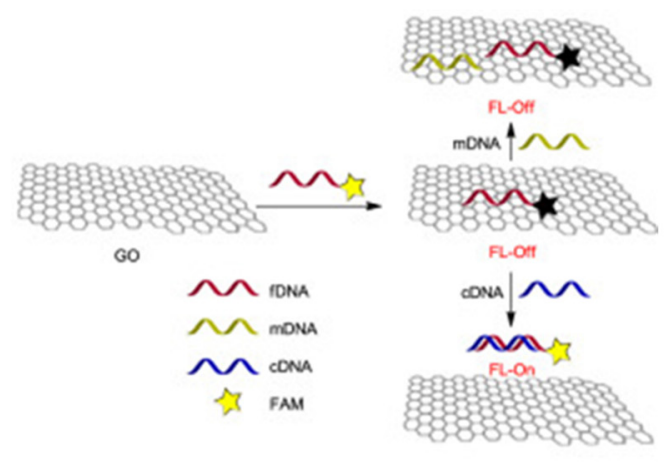

b

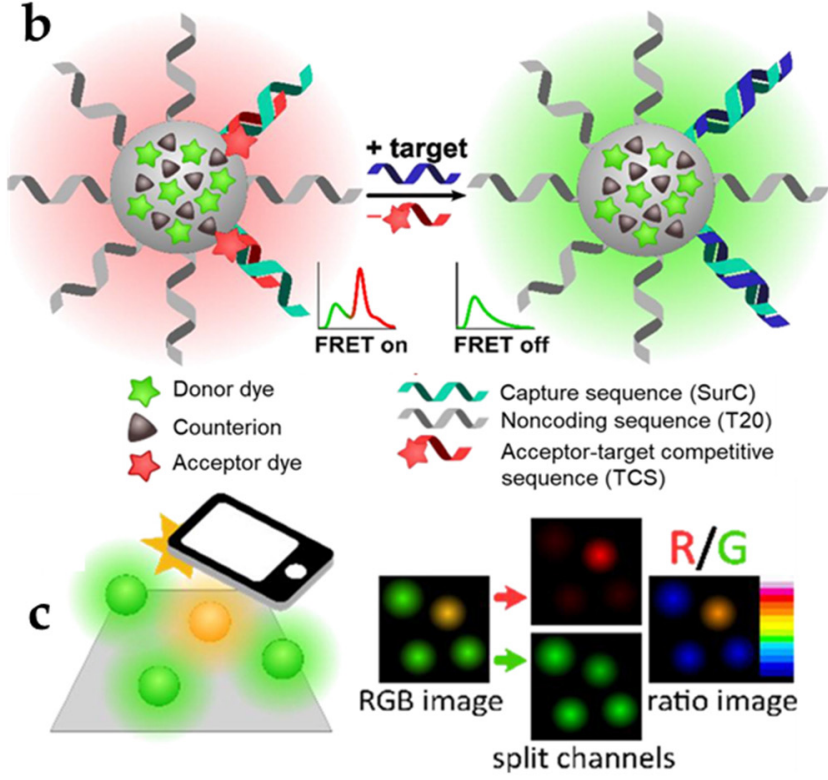

Figure 2. DNA target biosensor using nanomaterial-based FRET. (a) Schematic representation of the detection of a deletion mutation in exon 19 of the EFGR gene on a graphene oxide surface [68]. (b) Schematic diagram of the FRET-based RGB detection of DNA as a cancer biomarker by using a smartphone. This figure is reproduced from [64] (C 2016 Elsevier B.V.); Green emission from the nanoprobe (NP) surface transfers some of the excitation energy to the FRET receptor on the NP surface and, thereby, causes the NP to fluoresce in yellow-orange. (c) Smartphone-based data analysis. Green and red RGB images are taken, and intensity ratios between the channels are evaluated. This figure is reproduced from [66] (@ 2020 Elsevier B.V.).

\subsection{FRET-Based Biosensors for Detection of RNA Targets}

To realize low-level RNA detection in early cancer diagnosis and biological research, ultrasensitive, highly accurate, and fast RNA detection platforms have been developed. Among them, the use of a nanomaterial as a fluorescence quencher that effectively quenches the fluorescence of a fluorophore-conjugated probe via FRET is a widely used strategy. This technique offers advantages due to its large surface area and unique optical properties. Wang et al. reported the use of $\mathrm{Ti}_{3} \mathrm{C}_{2}$ nanosheets, a representative MXene, as biosensors for miRNA-21 detection [67]. Poly (acrylic acid) (PAA) decoration not only stabilized and increased the dispersion of the $\mathrm{Ti}_{3} \mathrm{C}_{2}$ nanosheets but also increased the number of covalent bonding sites for the subsequent surface DFNA functionalization. The detection limit of this strategy is $0.8 \mathrm{nM}$. Oudeng et al. developed Folic acid (FA)-functionalized $\mathrm{MoS}_{2}$ nanosheets immobilized with a fluorescently labeled single-stranded DNA probe (ssDNA$\mathrm{MoS}_{2}$-PEG-FA) to detect miRNA-21, which is highly expressed in lung and pancreatic cancers [68]. In this system, the FA part, conjugated via an LA-PEG linker, protects the ssDNA probe and thus improves the cancer cell targeting and internalization processes. A higher binding force between the target miRNA-21 and the ssDNA probe was enhanced through the improved internalization process due to the hybridization of the endogenous miRNA and FA-functionalized $\mathrm{MoS}_{2}$ nanosheets (FAM)-ssDNA, and a fast fluorescence signal was confirmed due to the separation of the dye-labeled ssDNA probe from the $\mathrm{MoS}_{2}$ nanosheets. Afzalinia et al. used an La (III) metal-organic framework (MOF) and silver 
NPs (AgNPs) as the energy donor-acceptor pair in fluorescence quenching to detect the atypically expressed miRNA-155 in patients with breast or lung cancer [69]. The use of MOFs with large surface area significantly improved the miRNA detection performance by increasing the number of aptamers attached to the probe surface. This system can detect as low as $0.04 \mathrm{ppb}(\mathrm{ng} / \mathrm{mL}$ ) or $5.5 \mathrm{fM}$ miRNA-155 (Figure 3a). Chu et al. developed a microfluidic biochip-based system that has an extremely low detection limit $(0.146 \mathrm{aM})$ and the capacity to simultaneously detect up to 20 miRNAs in $35 \mathrm{~min}$ from an exceedingly small amount of sample solution [70]. In this system, glass substrates are locally assembled with GO and PLL in the reaction and detection chambers, respectively. The GO immobilizes a FAM-labeled DNA probe, and fluorescence is extinguished when the DNA probe is immobilized on the GO. PLL adsorbs both ssDNA and DNA-miRNA complexes without fluorescence quenching and collects the DNA-miRNA complexes after the target miRNA reacts with the DNA probe (Figure $3 b$ ).

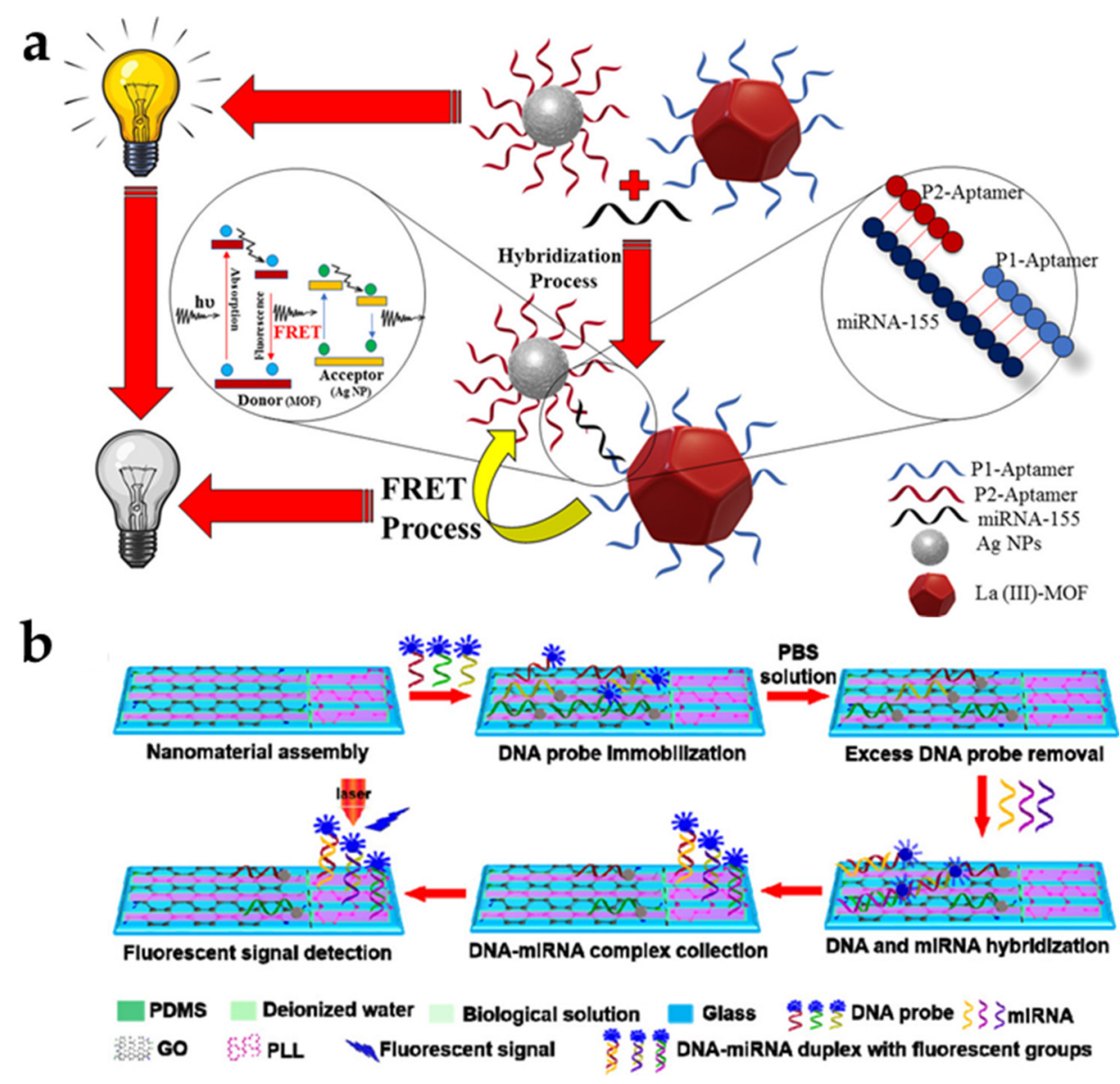

Figure 3. RNA target biosensor using nanomaterial-based FRET. (a) Schematic diagram of the FRETbased detection of miRNA-155 as a cancer biomarker by using La (III) metal-organic MOF and AgNPs. This figure is reproduced from [69] (@ 2021 American Chemical Society); (b) Schematic illustration of the multiplex miRNA-sensing principle of microfluidic biochips via single-stranded probe/DNAmiRNA duplexes and PLL-assembled detection microchambers. This figure is reproduced from [70] (C) 2021 American Chemical Society).

\section{MEF-Based Nucleic Acid Biosensors for Cancer Diagnosis 4.1. $M E F$}

MEF has attracted much interest in both fundamental studies and sensing applications. Fluorescent intensities of fluorophores and fluorescent NPs could be expressively amplified due to their interactions with NPs based on noble metals, such as $\mathrm{Au}, \mathrm{Ag}, \mathrm{Cu}$, and Pt [74-76]. The electromagnetic effect on the surface of the noble metal provides a 
significantly enhanced electric field, which enhances the excitation efficiency and increases the radiative decay rates of the fluorescent materials placed at the gap region. Consequently, the fluorescent intensities are increased. This MEF effect originates from the plasmon-coupling between the noble metal and fluorophores (Figure 1b). This fluorescence enhancement depends on the morphology and composition of the metal NPs, the distance between the metal NPs and fluorophores, and the absorption/emission spectral overlap between the metal NPs and fluorophores. Therefore, it is very important to design noble NPs with appropriated plasmonic properties to induce significant fluorescent enhancement. For the MEF effect, most of the fluorescent materials, including organic fluorophores, quantum dots, carbon dots, and upconversion NP, can be utilized coupled with noble NPs [77-80]. In addition, the MEF process simultaneously enhances the photostability and sensitivity as well as the intensities. Recently, MEF-based nanobiosensors have been developed to improve the detection sensitivity for target biomarkers, including nucleic acids and proteins, to the level of ultra-low concentrations $[74,81,82]$. The presence of fluorescent materials near the noble metal NPs increases the rate of excitation and emission by inducing the fluorophores to assume additional electron configurations. Based on this phenomenon, the MEF-based nanobiosensor consists of an optical transducer (fluorescent materials), and a signal amplifier (noble NPs) enables the construction of sensors simpler than those based on conventional fluorescence, which necessitates complicated steps to increase the detection sensitivity. In this regard, MEF is a promising tool for generating effective biosensors. Nucleic acid biomarkers have been known as excellent targets to diagnose several diseases, including cancer, due to the specific recognition of the complementary sequences. In addition, capture materials can be easily functionalized using various fluorophores and noble metal NPs. In this section, we discussed the currently developed MEF-based nanobiosensors for the detection of genetic materials to diagnose cancer. There are many studies on MEF-based nanobiosensors for nucleic acid detection (Table 2).

Table 2. Comparison of MEF-based nanobiosensors for nucleic acid detection.

\begin{tabular}{|c|c|c|c|c|c|c|}
\hline Detection Strategy & $\begin{array}{c}\text { Fluorescent } \\
\text { Dye/Enhancer }\end{array}$ & $\begin{array}{l}\text { Wavelengths } \\
\text { (Ex, Em) }\end{array}$ & Target & $\begin{array}{l}\text { Required } \\
\text { Time }\end{array}$ & $\begin{array}{l}\text { Detection } \\
\text { Limit }\end{array}$ & Ref \\
\hline $\begin{array}{l}\text { Detection of DNA by using } \\
\text { engineered substrates to increase } \\
\text { the emissivity of the fluorophore } \\
\text { (proximity of surface plasmons } \\
(<100 \AA))\end{array}$ & $\begin{array}{l}\text { Cy3, Cy5/Ag- } \\
\text { nanostructure }\end{array}$ & $\begin{array}{c}\text { Ex: } 549 \mathrm{~nm}, 646 \\
\text { nm } \\
\text { Em: } 562 \mathrm{~nm}, \\
663 \mathrm{~nm}\end{array}$ & DNA & $<3 \mathrm{~h}$ & - & [83] \\
\hline $\begin{array}{l}\text { By applying neutravidin-coated } \\
\text { fluorescent nanospheres to } \\
\text { biotinylated Au-nanorods, the } \\
\text { signal enhancement under the } \\
\text { fluorescence microscope using Ag } \\
\text { zigzag nanorods (ZNR) arrays }\end{array}$ & $\begin{array}{c}\text { Alexa 488/Ag } \\
\text { zigzag nanorod }\end{array}$ & $\begin{array}{l}\text { Ex: } 488 \mathrm{~nm} \\
\text { Em: } 525 \mathrm{~nm}\end{array}$ & DNA & $<3 \mathrm{~h}$ & $0.01 \mathrm{pM}$ & [84] \\
\hline $\begin{array}{l}\text { Induction of localized surface } \\
\text { plasmon resonance effect (LSPR) } \\
\text { of highly ordered monolayer } \\
\text { Au-nanorods; Distance-dependent } \\
\text { MEF effect between extinction and } \\
\text { enhancement }\end{array}$ & $\begin{array}{l}\text { Quasar670/Au- } \\
\text { nanorod }\end{array}$ & $\begin{array}{l}\text { Ex: } 664 \mathrm{~nm} \\
\text { Em: } 670 \mathrm{~nm}\end{array}$ & ssDNA & $<20 \min$ & $10 \mathrm{pM}$ & [85] \\
\hline $\begin{array}{l}\text { Detection of DNA by using Ag } \\
\text { vertical nanorod (VNR) arrays } \\
\text { fabricated via the glancing angle } \\
\text { deposition (GLAD) method }\end{array}$ & $\begin{array}{l}\text { Cy5/Ag } \\
\text { vertical } \\
\text { nanorods }\end{array}$ & $\begin{array}{l}\text { Ex: } 635 \mathrm{~nm} \\
\text { Em: } 670 \mathrm{~nm}\end{array}$ & $\begin{array}{l}\text { Kallikrein } \\
\text { (KLK7) }\end{array}$ & $>12 \mathrm{~h}$ & - & [86] \\
\hline
\end{tabular}


Table 2. Cont

\begin{tabular}{|c|c|c|c|c|c|c|}
\hline Detection Strategy & $\begin{array}{c}\text { Fluorescent } \\
\text { Dye/Enhancer }\end{array}$ & $\begin{array}{l}\text { Wavelengths } \\
\text { (Ex, Em) }\end{array}$ & Target & $\begin{array}{l}\text { Required } \\
\text { Time }\end{array}$ & $\begin{array}{l}\text { Detection } \\
\text { Limit }\end{array}$ & Ref \\
\hline $\begin{array}{l}\text { Bimetallic structures (containing } \\
\text { Au and } \mathrm{Ag} 2 \mathrm{~nm} \text { and } 50 \mathrm{~nm} \text { thick) } \\
\text { are used to maximize the MEF } \\
\text { effect; Detection of amplified } \\
\text { target DNA using polymerase } \\
\text { chain reaction (PCR). }\end{array}$ & $\begin{array}{l}\text { SYBR Green } \\
\text { I/Au-Ag }\end{array}$ & $\begin{array}{l}\text { Ex: } 470 \mathrm{~nm} \\
\text { Em: } 535 \mathrm{~nm}\end{array}$ & dsDNA & - & $400 \mathrm{fg} / \mu \mathrm{L}$ & [87] \\
\hline $\begin{array}{l}\text { Fix with capture DNA of magnetic } \\
\text { nanoparticles implanted with } \\
\text { silver nanoparticles; After } \\
\text { introduction of target DNA, } \\
\text { sandwich structure formation by } \\
\text { hybridization reaction and } \\
\text { isolation of barcode DNA from } \\
\text { silver nanoparticles and } \\
\text { fluorescence enhancement }\end{array}$ & $\begin{array}{c}\text { FAM/NMP- } \\
\text { AgNP }\end{array}$ & $\begin{array}{l}\text { Ex: } 495 \mathrm{~nm} \\
\text { Em: } 518 \mathrm{~nm}\end{array}$ & DNA & $>10 \min$ & $1 \mathrm{pM}$ & [88] \\
\hline $\begin{array}{l}\text { Increase the signal-to-background } \\
\text { ratio by using the high quenching } \\
\text { efficiency of AuNPs; } \\
\text { Distance-dependent MEF effect } \\
\text { and high specificity of target } \\
\text { fluorescein isothiocyanate-tagged } \\
\text { DNA-HMNC and target DNA } \\
\text { hybridization }\end{array}$ & $\begin{array}{c}\text { FITC / Magnetic } \\
\text { NP/nanogold } \\
\text { clusters }\end{array}$ & $\begin{array}{l}\text { Ex: } 488 \mathrm{~nm} \\
\text { Em: } 520 \mathrm{~nm}\end{array}$ & DNA & $>2 \mathrm{~h}$ & $0.01 \mu \mathrm{M}$ & [89] \\
\hline $\begin{array}{l}\text { Amine-functionalized } \mathrm{Fe}_{3} \mathrm{O}_{4} \\
\text { nanoparticles bind with } \\
\text { amine-gold bonding reaction and } \\
\text { form magnetic Au-nanoclusters; } \\
\text { After binding of target DNA, } \\
\text { distance-dependent MEF effect } \\
\text { between AuNP and FITC }\end{array}$ & $\begin{array}{c}\text { Flu, Rho 6G, } \\
\text { Cy5/MOF- } \\
\text { based } \\
\text { nanoprobes }\end{array}$ & $\begin{array}{c}\text { Ex: } 494,525, \\
\text { and } 646 \mathrm{~nm} \\
\text { Em: } 513 \mathrm{~nm}, \\
553 \mathrm{~nm}, 664 \mathrm{~nm}\end{array}$ & DNA & $<30 \min$ & $20 \mathrm{fM}$ & [90] \\
\hline $\begin{array}{l}\text { Quenching of AuNPconjugated } \\
\text { Cy5 by AuNP, complementary } \\
\text { binding of target DNA with } \\
\text { capture DNA on AuNP and other } \\
\text { DNA on Au-nanorod, AuNP or } \\
\text { Au@AgNP, and enhancement of } \\
\text { fluorescence signal. }\end{array}$ & $\begin{array}{c}\text { Au-NP- } \\
\text { conjugated } \\
\text { Cy5/Au@AgNP }\end{array}$ & $\begin{array}{l}\text { Ex: } 410 \mathrm{~nm} \\
\text { Em: } 660 \mathrm{~nm}\end{array}$ & DNA & $>12 \mathrm{~h}$ & $3.1 \mathrm{pM}$ & [91] \\
\hline $\begin{array}{l}\text { Length optimization of dsDNA } \\
\text { and attachment of } \\
\text { Au-nanoparticles (AuNPs) to the } \\
\text { surface; Activation of } \\
\text { CRISPR-Cas12a complex by target } \\
\text { cfDNA, degradation of AuNP and } \\
\text { fluorophore ssDNA, and } \\
\text { generation of red-violet } \\
\text { fluorescence }\end{array}$ & $\begin{array}{c}\text { FITC/DNA- } \\
\text { functionalized } \\
\text { AuNP }\end{array}$ & $\begin{array}{l}\text { Ex: } 490 \mathrm{~nm} \\
\text { Em: } 520 \mathrm{~nm}\end{array}$ & $\begin{array}{c}\text { breast } \\
\text { cancer } \\
\text { gene-1 } \\
\text { (BRCA-1) }\end{array}$ & $<30 \min$ & $0.34 \mathrm{fM}$ & [92] \\
\hline $\begin{array}{l}\text { Annealing of target RNA and } \\
\text { DNA anchor probes tagged with } \\
\text { silver nanoparticles and } \\
\text { fluorophores on a solid surface } \\
\text { and enhancement of fluorescence } \\
\text { signal }\end{array}$ & TAMRA/AgNP & $\begin{array}{l}\text { Ex: } 532 \mathrm{~nm} \\
\text { Em: } 585 \mathrm{~nm}\end{array}$ & $\begin{array}{l}\beta \text {-globin } \\
\text { mRNA }\end{array}$ & $30-60 \mathrm{~min}$ & $25 \mathrm{fM}$ & [93] \\
\hline
\end{tabular}


Table 2. Cont

\begin{tabular}{|c|c|c|c|c|c|c|}
\hline Detection Strategy & $\begin{array}{c}\text { Fluorescent } \\
\text { Dye/Enhancer }\end{array}$ & $\begin{array}{l}\text { Wavelengths } \\
\text { (Ex, Em) }\end{array}$ & Target & $\begin{array}{l}\text { Required } \\
\text { Time }\end{array}$ & $\begin{array}{l}\text { Detection } \\
\text { Limit }\end{array}$ & Ref \\
\hline $\begin{array}{l}\text { Fabrication of sandwich structure } \\
\text { using 484-mer RNA and 15-mer } \\
\text { complementary RNA attached to } \\
\text { Flower-like silver film; Enhanced } \\
\text { fluorescence emission of } \\
\text { TAMRA-tagged 15-mer RNA; } \\
\text { Shortening the spacing distance } \\
\text { between N-CD and } \mathrm{CeO}_{2} \text { and } \\
\text { significantly quenching the } \\
\text { fluorescence of N-CD; } \\
\text { Fluorescence recovery of } \\
\text { quenched probes in the presence } \\
\text { of target miRNAs }\end{array}$ & $\begin{array}{c}\left(\mathrm{DNA}_{1-}\right. \\
\mathrm{NCDs}) / \text { Flower- } \\
\text { like } \\
\mathrm{Ag}\end{array}$ & $\begin{array}{l}\text { Ex: } 390 \mathrm{~nm} \\
\text { Em: } 462 \mathrm{~nm}\end{array}$ & $\begin{array}{l}\text { miR-210, } \\
\text { miR-21 }\end{array}$ & $15 \mathrm{~min}$ & $\begin{array}{l}0.03 \mathrm{fM}, \\
0.06 \mathrm{fM}\end{array}$ & [94] \\
\hline $\begin{array}{l}\text { FAM-MB formed a hairpin } \\
\text { structure and the fluorescence } \\
\text { reduction of 6-FAM and AgNPs; } \\
\text { Upon target miRNA } \\
\text { hybridization, increasing the } \\
\text { distance between 6-FAM and } \\
\text { AgNPs and Fluorescence } \\
\text { enhancement }\end{array}$ & $\begin{array}{l}\text { FAM-tagged } \\
\text { MB/AgNRs }\end{array}$ & $\begin{array}{l}\text { Ex: } 488 \mathrm{~nm} \\
\text { Em: } 520 \mathrm{~nm}\end{array}$ & miR-21 & $60 \mathrm{~min}$ & $1 \mathrm{pM}$ & [95] \\
\hline $\begin{array}{l}\text { Fluorescent dye (FAM) tagging of } \\
\text { chemically synthesized gold } \\
\text { triangular nanoprisms (Au TNPs); } \\
\text { When the target miRNA } \\
\text { hybridizes with the molecular } \\
\text { beacon, the distance between the } \\
\text { FAM and AgNP increases and the } \\
\text { fluorescence intensity of the FAM } \\
\text { increases. }\end{array}$ & FAM/Au TNPs & $\begin{array}{l}\text { Ex: } 488 \mathrm{~nm} \\
\text { Em: } 520 \mathrm{~nm}\end{array}$ & $\begin{array}{l}\text { miR-10b, } \\
\text { miR-96 }\end{array}$ & $120 \mathrm{~min}$ & $\begin{array}{l}1.13 \mathrm{pM}, \\
30 \mathrm{fM}\end{array}$ & [96] \\
\hline $\begin{array}{l}\text { Fluorescence enhancement using } \\
\text { biotin-functionalized lanthanide } \\
\text { nanoparticles as signal enhancers } \\
\text { and capture of target miRNAs of } \\
\text { surface-modified molecular labels; } \\
\text { Detection of Biotin-NPs-probe } \\
\text { hybridized with miR in a } \\
\text { sandwich structure. }\end{array}$ & $\begin{array}{l}\text { Biotin- } \\
\text { NPs } / \mathrm{Ln}^{3+}- \\
\text { nanoprobe }\end{array}$ & $\begin{array}{l}\text { Ex: } 340 \mathrm{~nm} \\
\text { Em: } 617 \mathrm{~nm}\end{array}$ & miR-21 & $>2 \mathrm{~h}$ & $1.38 \mathrm{fM}$ & [97] \\
\hline $\begin{array}{l}\text { The miR-124 specific MB } \\
\text { (molecular beacon) attachment on } \\
\text { magnetic plasmonic nanorods; } \\
\text { Immunomagnetic isolation and } \\
\text { enrichment of exosomes in cell } \\
\text { culture medium collection, } \\
\text { non-destructive analysis of } \\
\text { exosome miR-124 expression. }\end{array}$ & $\begin{array}{c}\text { FAM/plasmonic } \\
\text { AuNRs }\end{array}$ & $\begin{array}{l}\text { Ex: } 490 \mathrm{~nm} \\
\text { Em: } 520 \mathrm{~nm}\end{array}$ & miR-124 & $30 \mathrm{~min}$ & $1 \mathrm{pM}$ & [98] \\
\hline
\end{tabular}

\subsection{MEF-Based Biosensors for Detection of DNA Targets}

Among the various DNA analytical methods, DNA microarray technologies have been widely used for disease diagnosis and DNA re-sequencing. For the detection of a target DNA, fluorescent materials are applied to translate the hybridization into a fluorescent signal. However, the sensitivity of fluorescence imaging is relatively low because the short half-lives of fluorescent probes restrict the photon intensity. Therefore, enhancement of the fluorescent signal is essential to sensitively quantitate the DNA target for precise and early 
diagnosis. An Ag-nanostructure was one of the remarkable substrates used for inducing MEF in a sensitive DNA microarray-based system [83]. The Ag-nanostructures on the films provided a 28-time intense signal from the near-infrared dye Cy5, compared with that obtained using glass substrates. In the case of DNA hybridization, its sensitivity increased 10-fold for Cy5 and 2.5-fold for Cy3. Ji et al. synthesized a zigzag-shaped Ag-nanorod to improve the MEF effect and found the optimal folding number to be seven, whose scattering intensity was maximized [84]. For the verification of the enhancement factor, neutravidincoated fluorescent nanospheres were applied onto the biotinylated Au-nanorods, whereby a 14-fold increase in the emission intensity was obtained. This condition also enabled highly sensitive detection of DNA, as low as $0.01 \mathrm{pM}$ concentration. Mei et al. developed a monolayered Au-nanorod in a highly ordered form for the induction of the localized surface plasmon resonance effect (LSPR). This system involves hot spots generated between the neighboring particle tips in the nanoarray [85]. Through this plasmonic effect, MEF was found to be dependent on the excitation and emission wavelengths of the fluorophore, greater than $600 \mathrm{~nm}$. Using this phenomenon, a sensitive MEF-based biosensor was developed by integrating the molecular beacon detection technique in a chip-based format for ultrasensitive DNA analysis, as low as $1 \mathrm{pM}$. Badshah et al. achieved sensitive detection of DNA by using Ag vertical nanorod (VNR) arrays fabricated via the glancing angle deposition (GLAD) method (Figure 4a) [86]. A homogeneous VNR nanoarray generated at a specific incident angle $\left(\theta=85^{\circ}\right)$ with substrate rotation produced a better MEF effect than slanted nanorods (SNRs). In the case of the size, a maximum enhancement factor of approximately 200 times was attained on the NR substrate with a size of $500 \mathrm{~nm}$, compared with the commercially available amine slide. Tran et al. used a bimetallic structure to maximize the MEF effect (Figure 4b) [87]. This bimetallic condition involved Au and Ag at a thickness of 2 and $50 \mathrm{~nm}$, respectively. Under these conditions, a better local field was obtained, compared with that obtained using monometallic structures with an SYBR Greenconjugated double-stranded DNA. Using this nanosubstrate, the target DNA, amplified using polymerase chain reaction (PCR), was successfully quantitated at a concentration as low as $400 \mathrm{fg} / \mu \mathrm{L}$ and with reduced photobleaching. The authors claimed that this bimetallic nanosubstrate could provide a highly reproducible and sensitive platform for fluorescent-based DNA detection from a small sample volume in multiplexed diagnosis. 

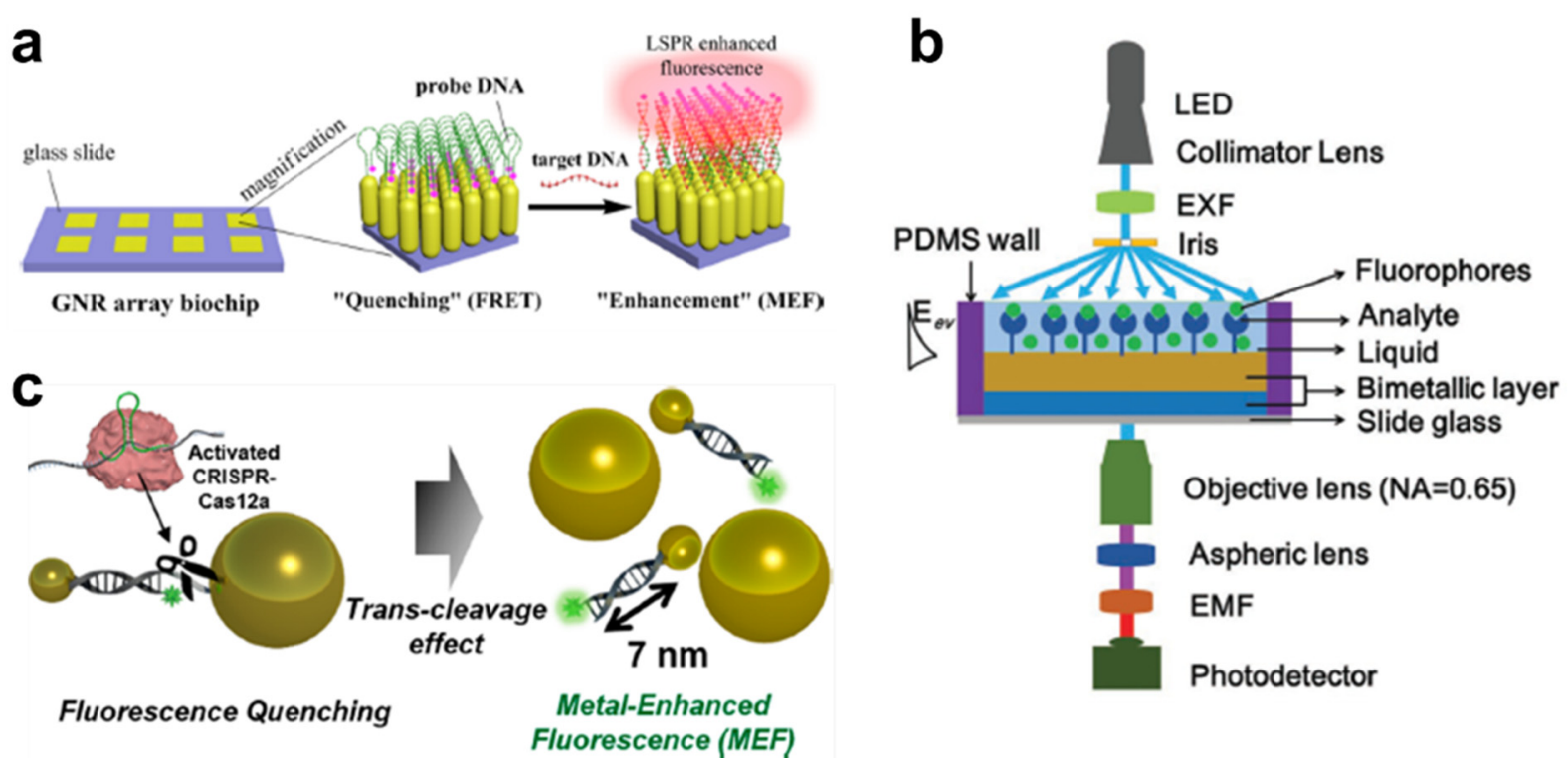

Figure 4. MEF-based nanobiosensor for DNA detection. (a) Schematic diagram of vertical Au-nanorod array for MEFassisted DNA detection. This figure is reproduced from [86] (ㅇ 2017 American Chemical Society); (b) The straight (transmission) geometry-based bimetallic biosensing platform for the MEF-assisted DNA-detection system. This figure is reproduced from [87] (C 2018 John Wiley \& Sons); (c) Schematic illustration of the CRISPR-Cas12a-based fluorescent biosensor for detection of DNA via a MEF using DNA-functionalized AuNPs without nucleic acid amplification. This figure is reproduced from [92] (C 2021 American Chemical Society).

In addition to the microarray system, solution-based DNA analytical methods have been widely developed using the nanomaterial-assisted MEF effect. Zhou et al. developed an AgNP-mediated DNA-detection system by using the MEF effect on the fluorophore (FAM) [88]. Because the AgNP modified two different DNAs, namely the capture DNA and barcode DNA, with FAM, this system could detect the target DNA and enhance the fluorescent signals simultaneously. The target DNA could induce the magnetic NP and AgNP to assume a sandwich conformation due to the hybridization reaction. After the magnetic separation method, DNA could be measured at a concentration as low as $1 \mathrm{pM}$ and with high sensitivity and simplicity. Gu et al. utilized the hybrid magnetic Au-nanoclusters to induce the MEF effect via the hybridization of the target DNA [89]. To form a unique magnetic Au-nanocluster, amine-functionalized $\mathrm{Fe}_{3} \mathrm{O}_{4} \mathrm{NPs}$ were applied to the AuNP to couple with the amine-Au binding reaction. The fluorescein isothiocyanate (FITC)-tagged capture DNA was functionalized on the AuNPs for the detection of the target DNA, whereby a significant distance-dependent MEF effect between the AuNP and FITC was obtained if the target DNA was bound to the capture DNA. In this study, the suitable distance for the MEF effect was estimated at approximately $4 \mathrm{~nm}$, and the enhancement factor was approximately 10 . Wu et al. developed a novel fluorescent nanoprobe consisting of a metal-organic framework (MOF), which is a highly ordered nanoporous structure with thermal stability [90]. The advantage of the MOF is a higher surface-to-volume ratio than the typical NPs because of their high porosity. Thus, a high quantity of molecular beaconstructured DNA could be attached from the core to the surface of the MOF. Additionally, the target DNA induced a fluorescent enhancement effect by displacing the fluorescent dye from the surface of the MOF. This MOF-based MEF system could quantitate a target DNA with a detection limit of $20 \mathrm{fM}$ and with high selectivity. Zhu et al. identified the optimal size and shape of the metal NP for sensitive MEF-based DNA detection [91]. The AuNPconjugated Cyanine 5 (Cy5) was quenched by the energy transfer to the AuNP. After the complementary binding of the target DNA with the capture DNA on the AuNP and another DNA on the Au-nanorod, AuNP, or Au@AgNP, the fluorescent signals could be enhanced by the MEF effect. Of the three different NPs, Au@AgNP showed the most enhanced result, which was approximately 100 times that of the quenched state. Using this coupled 
nanostructure, the target DNA could be detected at a concentration as low as $3.1 \mathrm{pM}$ and without the pulse-positive signal of the single-mismatched DNA. Our group has developed a DNA-detection system by changing the quenched MEF state through the modulation of the target DNA concentration (Figure 4c) [92]. The $20 \mathrm{~nm}$ and $60 \mathrm{~nm}$ AuNPs connected by the double-stranded and single-stranded DNA. If the CRISPR-Cas12a was activated by the target DNA, it randomly cleaved the ambient single-stranded DNA, and the $20 \mathrm{~nm}$ AuNPs apart from another AuNP. This phenomenon induced the MEF effect between the fluorophore and the $20 \mathrm{~nm}$ AuNP, and the target DNA was sensitively quantitated within $30 \mathrm{~min}$ at a concentration ranging from $1 \mathrm{fM}$ to $100 \mathrm{pM}$. Thus, metal NPs can assist the sensitive detection of DNA through the metal-based fluorescence enhancement effect in both DNA microarrays and solution-based systems.

\subsection{MEF-Based Biosensors for Detection of RNA Targets}

As mentioned before, RNA molecules are also potential biomarkers for the diagnosis of several diseases because of the potential pathophysiological roles of these molecules. Therefore, there have been several attempts to quantitate specific RNAs by integrating the nanomaterial-assisted MEF effect. The first attempt was approximately 15 years ago and consisted of a silver-island film on a glass substrate [93]. In this system, a 484-mer RNA is attached to the silver-island film via two 15-mer complementary RNAs as a sandwich structure. A TAMRA-tagged 15-mer RNA emits enhanced fluorescence and can successfully detect a low concentration of RNA ( 25 fM). Recently, Liang et al. developed the flower-like silver (FLS)-enhanced fluorescence biosensor for ultrasensitive detection of multiple miRNAs (Figure 5a) [94]. To simplify the detection process, the authors applied the multi-channel microfluidic paper-based analytical devices ( $\mu$ PADs) to the MEF-based biosensing system. The carbon dot and nanoceria $\left(\mathrm{CeO}_{2}\right)$ were conjugated to each other before the binding of the target miRNA, and the fluorescent signal was quenched due to the $\mathrm{CeO}_{2}$. After hybridization of the target miRNA to the carbon dot-modified capture DNA, the signal emitted by the carbon dot was enhanced, and the target miRNA, at the concentration of as low as $0.03 \mathrm{pM}$, could be quantitated. Simultaneously, $\mathrm{CeO}_{2}$ showed the catalytic activity on the $\mathrm{H}_{2} \mathrm{O}_{2}$, which was one of the reactive oxygen species. This platform could provide the real-time monitoring of miRNAs and $\mathrm{H}_{2} \mathrm{O}_{2}$ with high sensitivity and selectivity. Wang et al. have developed a microfluidic-based miRNA detection platform, which consisted of surface-enhanced Raman scattering (SERS) and a MEF-inducing nanosystem [95]. AgNPs were immobilized on a glass substrate, forming SERS and MEF substrates simultaneously with a Raman and fluorescent dye (FAM)-tagged molecular beacon. When the target miRNA hybridized with the molecular beacon, it increased the distance between the FAM and AgNP, and the fluorescent intensity of the FAM increased, whereas the SERS signal decreased. By combining the reverse changes, the target miRNA, at a concentration of as low as $1 \mathrm{pM}$, could be detected with reduced reaction duration and complexity. This dual analytical strategy can circumvent each disadvantage and stand out for each advantage. Masterson et al. synthesized Au-based triangular nanoprisms and applied them to a nanoplasmonic biosensing platform for sensitive miRNA detection [96]. This triangular nanostructure facilitated the induction of the plasmonic effect, thereby inducing both SERS and MEF effects. By using this system, the oncogenic miRNAs (miR-10b and miR-96) in the serum of a patient were directly quantitated with high sensitivity (at the sub-fg/ $\mu \mathrm{L}$ level). Importantly, the dual-sensing nature of this system prevents false positive and negative responses. 


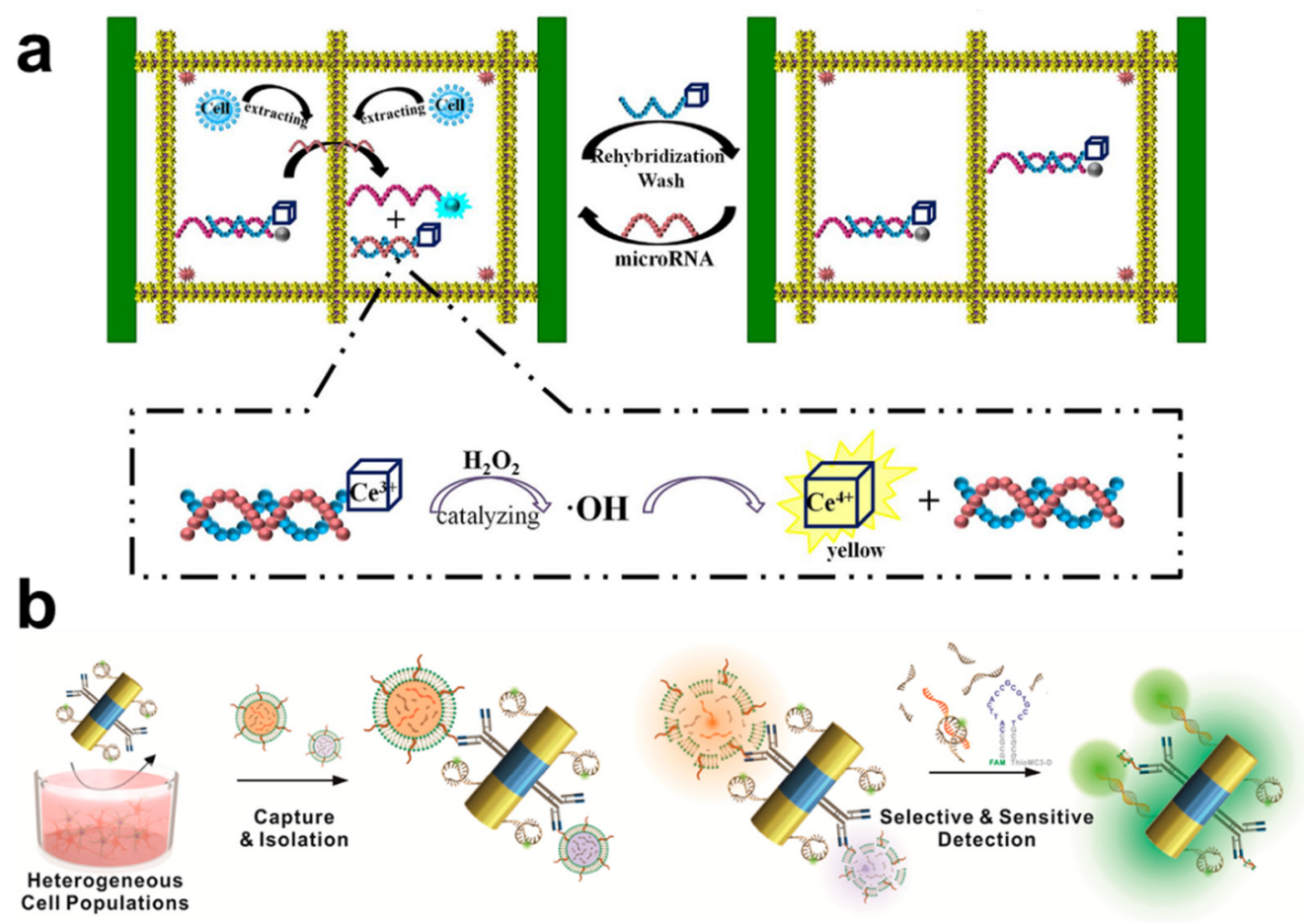

Figure 5. MEF-based RNA nanobiosensors. (a) Schematic diagram of the Au-based triangular nanoprism biosensor for detection of miRNAs via the SERS and MEF methods. This figure is reproduced from [94] (@ 2017 Elsevier B.V.); (b) Schematic illustration of exosomal miRNA detection by using multifunctional Au-Ni-Au nanorods via the MEF effect. This figure is reproduced from [98] (ㄷ 2019 American Chemical Society).

Solution-based sensitive detection of RNA has also been studied using several detection strategies with metal NPs. Lu et al. developed miRNA biosensors via a fluorescence enhancement strategy with biotin-functionalized lanthanide NPs as signal enhancers [97]. A surface-modified molecular beacon could capture the target miRNA, and the biotinylated detection probe hybridized with the miRNA as a sandwich structure. The enhanced fluorescent signal from the lanthanide NPs provides sensitive detection, ranging from $10 \mathrm{fM}$ to $100 \mathrm{pM}$, with a detection limit as low as $1.38 \mathrm{fM}$, which is three orders of magnitude better than the typical fluorescent probes. Our research group has detected exosomal miRNAs by using MEF with a triblock nanorod, which consisted of Au-Ni-Au (Figure 5b) [98]. FAMtagged molecular beacon modified on the surface of Au with the quenched state. Once the antibody on the Ni surface captures the exosomes, they are separated by the magnetic force, and any ejected exosomal miRNA binds to the molecular beacon specifically. The unfolded molecular beacon can emit an enhanced fluorescence signal due to the plasmonic effect of the Au-nanorod. Using this particle-based MEF sensing system, miR-124, which is closely related to neuronal differentiation, has been measured in a highly sensitive manner, as low as $1 \mathrm{pM}$. This method could also characterize a heterogeneous population of neural cells, including neurons and astrocytes, in an in vitro cell culture model and ex vivo rodent model. We anticipate that this multi-segmented MEF-based exosomal miRNA biosensing platform has a prodigious potential to diagnose several cancers and investigate intra- and extracellular communications with high sensitivity.

\section{Outlook and Conclusions}

Nanomaterials can enhance the fluorescent signal via MEF, and ultrasensitive detection of target genetic materials has been achieved for the early diagnosis of several diseases and observation of cell-cell interactions. However, there is still room to improve for precise, accurate, and early diagnosis. For a precise and accurate diagnosis, measurement of only one nucleic acid biomarker is insufficient, even though the result of such detection shows high reliability. To solve this problem, additional biomarkers should be identified. A 
multi-analyte detection system can provide a precise diagnosis. For example, quantitation of a single miRNA cannot indicate the exact state of cancer. However, a multi-miRNA analysis can provide more information about the cancers [99-101]. In this perspective, nanomaterial-based fluorescent biosensors should be developed to quantitate multiple nucleic acids simultaneously. Fluorescent nanomaterials, including upconversion NPs or quantum dots, can be applied to the multi-detection platform by virtue of their specific emission peaks and higher quantum yield than typical organic dyes. For early diagnosis, a sensitive detection system should be developed to measure infinitesimal changes in the amount of nucleic acid biomarkers. As mentioned previously, nanomaterials can improve the sensitivity as well as selectivity and shorten the assay time. Furthermore, fluorescent-based analytical methods as well as electrochemical, electrical, and other optical methods have also been applied to quantitate nucleic acid biomarkers at a highly sensitive level. Such nanomaterial-based biosensors should be integrated into user-friendly devices, such as a disposable, wearable, or smartphone-based point-of-care testing system. These integrated systems will enable the treatment of the disease quickly and with the proper treatment methods and drugs.

In conclusion, we reviewed the recent progress in the use of nanotechnology-based FRET and MEF biosensors for the detection of nucleic acid biomarkers. Compared with conventional fluorescence biosensors, FRET and MEF exhibit superb performances, such as intensive emission spectra for sensitive detection. As well as nucleic acid biomarkers, other biomolecules, such as enzymes, have been measured using NP-assisted FRET and MEF. In addition, these analytical methods can provide the intuitive result upon integration to other platforms, such as disposable or smartphone-based systems. As a result, FRET and MEF biosensing platforms for sensitive, selective, simple, and rapid detection will be further developed using various nanotechnologies to improve the current detection performances. The advanced fluorescence-based sensing platform with superior properties of nanomaterials will provide personalized therapies with precise and detailed diagnostic results to increase the recovery rate in several diseases, including cancers.

Author Contributions: J.-H.C., T.H. and J.-W.C., S.-N.L. organized the structure of the manuscript. J.H.C. and T.H., wrote the whole manuscript. M.S. revised the manuscript. All authors collaboratively wrote the manuscript. All authors have read and agreed to the published version of the manuscript.

Funding: This research was supported by the National Research Foundation of Korea (NRF) grant funded by the Korea government (MSIT) (No.2019R1A2C3002300), and Basic Science Research Program through the National Research Foundation of Korea (NRF) funded by the Ministry of Education (2016R1A6A1A03012845), and "Research Base Construction Fund Support Program" funded by Jeonbuk National University in 2021.

Institutional Review Board Statement: Not applicable.

Informed Consent Statement: Not applicable.

Data Availability Statement: Not applicable.

Conflicts of Interest: The authors declare no conflict of interest. The funders had no role in the design of the study; in the collection, analyses, or interpretation of data; in the writing of the manuscript, or in the decision to publish the results.

\section{References}

1. Armstrong, A.J.; Lin, P.; Tombal, B.; Saad, F.; Higano, C.S.; Joshua, A.M.; Parli, T.; Rosbrook, B.; van Os, S.; Beer, T.M. Five-year Survival Prediction and Safety Outcomes with Enzalutamide in Men with Chemotherapy-naive Metastatic Castration-resistant Prostate Cancer from the PREVAIL Trial. Eur. Urol. 2020, 78, 347-357. [CrossRef]

2. Hong, Y.; Kim, J.; Choi, Y.J.; Kang, J.G. Clinical study of colorectal cancer operation: Survival analysis. Korean J. Clin. Oncol. 2020, 16, 3-8. [CrossRef]

3. van Rijt, S.H.; Sadler, P.J. Current applications and future potential for bioinorganic chemistry in the development of anticancer drugs. Drug Discov. Today 2009, 14, 1089-1097. [CrossRef]

4. Kashyap, D.; Kaur, H. Cell-free miRNAs as non-invasive biomarkers in breast cancer: Significance in early diagnosis and metastasis prediction. Life Sci. 2020, 246, 117417. [CrossRef] [PubMed] 
5. Wang, L.; Yao, M.; Dong, Z.; Zhang, Y.; Yao, D. Circulating specific biomarkers in diagnosis of hepatocellular carcinoma and its metastasis monitoring. Tumour Biol. 2014, 35, 9-20. [CrossRef] [PubMed]

6. $\quad$ deVos, T.; Tetzner, R.; Model, F.; Weiss, G.; Schuster, M.; Distler, J.; Steiger, K.V.; Grutzmann, R.; Pilarsky, C.; Habermann, J.K.; et al. Circulating Methylated SEPT9 DNA in Plasma Is a Biomarker for Colorectal Cancer. Clin. Chem. 2009, 55, 1337-1346. [CrossRef]

7. Meng, S.; Zhou, H.; Feng, Z.; Xu, Z.; Tang, Y.; Li, P.; Wu, M. CircRNA: Functions and properties of a novel potential biomarker for cancer. Mol. Cancer 2017, 16, 94. [CrossRef] [PubMed]

8. Borrebaeck, C.A. Precision diagnostics: Moving towards protein biomarker signatures of clinical utility in cancer. Nat. Rev. Cancer 2017, 17, 199-204. [CrossRef] [PubMed]

9. Davis, V.W.; Bathe, O.F.; Schiller, D.E.; Slupsky, C.M.; Sawyer, M.B. Metabolomics and surgical oncology: Potential role for small molecule biomarkers. J. Surg. Oncol. 2011, 103, 451-459. [CrossRef]

10. Lin, S.Y.; Linehan, J.A.; Wilson, T.G.; Hoon, D.S.B. Emerging Utility of Urinary Cell-free Nucleic Acid Biomarkers for Prostate, Bladder, and Renal Cancers. Eur. Urol. Focus 2017, 3, 265-272. [CrossRef]

11. Lim, S.H.; Becker, T.M.; Chua, W.; Caixeiro, N.J.; Ng, W.L.; Kienzle, N.; Tognela, A.; Lumba, S.; Rasko, J.E.J.; de Souza, P.; et al. Circulating tumour cells and circulating free nucleic acid as prognostic and predictive biomarkers in colorectal cancer. Cancer Lett. 2014, 346, 24-33. [CrossRef]

12. Davis-Dusenbery, B.N.; Hata, A. MicroRNA in Cancer: The Involvement of Aberrant MicroRNA Biogenesis Regulatory Pathways. Genes Cancer 2010, 1, 1100-1114. [CrossRef] [PubMed]

13. Lapin, M.; Oltedal, S.; Tjensvoll, K.; Buhl, T.; Smaaland, R.; Garresori, H.; Javle, M.; Glenjen, N.I.; Abelseth, B.K.; Gilje, B.; et al. Fragment size and level of cell-free DNA provide prognostic information in patients with advanced pancreatic cancer. J. Transl. Med. 2018, 16, 300. [CrossRef]

14. Bu, J.; Shim, J.E.; Lee, T.H.; Cho, Y.H. Multi-modal liquid biopsy platform for cancer screening: Screening both cancer-associated rare cells and cancer cell-derived vesicles on the fabric filters for a reliable liquid biopsy analysis. Nano Converg. 2019, 6, 1-8. [CrossRef]

15. Nunna, B.B.; Mandal, D.; Lee, J.U.; Singh, H.; Zhuang, S.; Misra, D.; Bhuyian, M.N.U.; Lee, E.S. Detection of cancer antigens (CA125) using gold nano particles on interdigitated electrode-based microfluidic biosensor. Nano Converg. 2019, 6, 1-12. [CrossRef] [PubMed]

16. Faltin, B.; Zengerle, R.; von Stetten, F. Current methods for fluorescence-based universal sequence-dependent detection of nucleic acids in homogenous assays and clinical applications. Clin. Chem. 2013, 59, 1567-1582. [CrossRef]

17. Zhang, M.Y.; Ye, J.; He, J.S.; Zhang, F.; Ping, J.F.; Qian, C.; Wu, J. Visual detection for nucleic acid-based techniques as potential on-site detection methods. A review. Anal. Chim. Acta 2020, 1099, 1-15. [CrossRef]

18. Kim, D.W.; Chun, H.J.; Kim, J.H.; Yoon, H.; Yoon, H.C. A non-spectroscopic optical biosensor for the detection of pathogenic Salmonella Typhimurium based on a stem-loop DNA probe and retro-reflective signaling. Nano Converg. 2019, 6, 1-8. [CrossRef]

19. Kricka, L.J.; Fortina, P. Analytical ancestry: “Firsts” in fluorescent labeling of nucleosides, nucleotides, and nucleic acids. Clin. Chem. 2009, 55, 670-683. [CrossRef] [PubMed]

20. Zhang, J.Y.; Xing, B.L.; Song, J.Z.; Zhang, F.; Nie, C.Y.; Jiao, L.; Liu, L.B.; Lv, F.T.; Wang, S. Associated Analysis of DNA Methylation for Cancer Detection Using CCP-Based FRET Technique. Anal. Chem. 2014, 86, 346-350. [CrossRef] [PubMed]

21. Yang, Y.; Huang, J.; Yang, X.; Quan, K.; Wang, H.; Ying, L.; Xie, N.; Ou, M.; Wang, K. FRET Nanoflares for Intracellular mRNA Detection: Avoiding False Positive Signals and Minimizing Effects of System Fluctuations. J. Am. Chem. Soc. 2015, 137, 8340-8343. [CrossRef]

22. Liu, J.; Li, S.; Bhethanabotla, V.R. Integrating Metal-Enhanced Fluorescence and Surface Acoustic Waves for Sensitive and Rapid Quantification of Cancer Biomarkers from Real Matrices. ACS Sens. 2018, 3, 222-229. [CrossRef] [PubMed]

23. Jeong, Y.; Kook, Y.M.; Lee, K.; Koh, W.G. Metal enhanced fluorescence (MEF) for biosensors: General approaches and a review of recent developments. Biosens. Bioelectron. 2018, 111, 102-116. [CrossRef] [PubMed]

24. Cheng, Y.; He, C.; Wang, M.; Ma, X.; Mo, F.; Yang, S.; Han, J.; Wei, X. Targeting epigenetic regulators for cancer therapy: Mechanisms and advances in clinical trials. Signal Transduct. Target. Ther. 2019, 4, 1-39. [CrossRef] [PubMed]

25. Bhattacharyya, S.; Yu, Y.; Suzuki, M.; Campbell, N.; Mazdo, J.; Vasanthakumar, A.; Bhagat, T.D.; Nischal, S.; Christopeit, M.; Parekh, S. Genome-wide hydroxymethylation tested using the HELP-GT assay shows redistribution in cancer. Nucleic Acids Res. 2013, 41, 157. [CrossRef]

26. Chen, H.-Y.; Wei, J.-R.; Pan, J.-X.; Zhang, W.; Dang, F.-Q.; Zhang, Z.-Q.; Zhang, J. Spectroscopic quantification of 5hydroxymethylcytosine in genomic DNA using boric acid-functionalized nano-microsphere fluorescent probes. Biosens. Bioelectron. 2017, 91, 328-333. [CrossRef] [PubMed]

27. Yang, Z.; Jiang, W.; Liu, F.; Zhou, Y.; Yin, H.; Ai, S. A novel electrochemical immunosensor for the quantitative detection of 5-hydroxymethylcytosine in genomic DNA of breast cancer tissue. Chem. Commun. 2015, 51, 14671-14673. [CrossRef]

28. Chen, S.; Dou, Y.; Zhao, Z.; Li, F.; Su, J.; Fan, C.; Song, S. High-sensitivity and high-efficiency detection of DNA hydroxymethylation in genomic DNA by multiplexing electrochemical biosensing. Anal. Chem. 2016, 88, 3476-3480. [CrossRef] [PubMed]

29. Wang, H.; Liu, M.; Bai, W.; Sun, H.; Li, Y.; Deng, H. A convenient electrogenerated chemiluminescence biosensing method for selective detection of 5-hydroxymethylcytosine in genomic DNA. Sens. Actuators B Chem. 2019, 284, 236-242. [CrossRef] 
30. Ma, Y.; Zhang, H.; Liu, F.; Wu, Z.; Lu, S.; Jin, Q.; Zhao, J.; Zhong, X.; Mao, H. Highly sensitive detection of DNA methylation levels by using a quantum dot-based FRET method. Nanoscale 2015, 7, 17547-17555. [CrossRef]

31. Gao, F.; Fan, T.; Ou, S.; Wu, J.; Zhang, X.; Luo, J.; Li, N.; Yao, Y.; Mou, Y.; Liao, X. Highly efficient electrochemical sensing platform for sensitive detection DNA methylation, and methyltransferase activity based on Ag NPs decorated carbon nanocubes. Biosens. Bioelectron. 2018, 99, 201-208. [CrossRef] [PubMed]

32. Zhang, Q.; Wu, Y.; Xu, Q.; Ma, F.; Zhang, C.-Y. Recent advances in biosensors for in vitro detection and in vivo imaging of DNA methylation. Biosens. Bioelectron. 2020, 112712. [CrossRef] [PubMed]

33. Chen, D.; Wu, Y.; Hoque, S.; Tilley, R.D.; Gooding, J.J. Rapid and ultrasensitive electrochemical detection of circulating tumor DNA by hybridization on the network of gold-coated magnetic nanoparticles. Chem. Sci. 2021, 12, 5196-5201. [CrossRef]

34. Li, D.; Xu, Y.; Fan, L.; Shen, B.; Ding, X.; Yuan, R.; Li, X.; Chen, W. Target-driven rolling walker based electrochemical biosensor for ultrasensitive detection of circulating tumor DNA using doxorubicin@ tetrahedron-Au tags. Biosens. Bioelectron. 2020, 148, 111826. [CrossRef] [PubMed]

35. Zhao, J.; Liu, C.; Li, Y.; Ma, Y.; Deng, J.; Li, L.; Sun, J. Thermophoretic detection of exosomal microRNAs by nanoflares. J. Am. Chem. Soc. 2020, 142, 4996-5001. [CrossRef] [PubMed]

36. Moon, J.; Lim, J.; Lee, S.; Son, H.Y.; Rho, H.W.; Kim, H.; Kang, H.; Jeong, J.; Lim, E.-K.; Jung, J. Urinary exosomal mRNA detection using novel isothermal gene amplification method based on three-way junction. Biosens. Bioelectron. 2020, 167, 112474. [CrossRef]

37. Ayakannu, T.; Taylor, A.H.; Konje, J.C. Selection of Endogenous Control Reference Genes for Studies on Type 1 or Type 2 Endometrial Cancer. Sci. Rep. 2020, 10,1-10. [CrossRef]

38. Chang, J.; Zhang, Y.; Li, Y.; Han, Z.; Tian, F.; Liu, C.; Feng, Q.; Wang, Y.; Sun, J.; Zhang, L. Multilayer Ratiometric Fluorescent Nanomachines for Imaging mRNA in Live Cells. Small Methods 2021, 5, 2001047. [CrossRef]

39. Zhang, M.; Hong, H.; Fen-Yue, Z.; Zhong, J.-C.; Jian-Ping, L. Electrochemical luminescent DNA sensor based on polymeraseassisted signal amplification. Chin. J. Anal. Chem. 2018, 46, 203-209. [CrossRef]

40. Yang, L.; Li, J.; Pan, W.; Wang, H.; Li, N.; Tang, B. Fluorescence and photoacoustic dual-mode imaging of tumor-related mRNA with a covalent linkage-based DNA nanoprobe. Chem. Commun. 2018, 54, 3656-3659. [CrossRef]

41. Zhong, L.; Cai, S.; Huang, Y.; Yin, L.; Yang, Y.; Lu, C.; Yang, H. DNA octahedron-based fluorescence nanoprobe for dual tumor-related mRNAs detection and imaging. Anal. Chem. 2018, 90, 12059-12066. [CrossRef]

42. Islam, M.N.; Gopalan, V.; Haque, M.H.; Masud, M.K.; Al Hossain, M.S.; Yamauchi, Y.; Nguyen, N.-T.; Lam, A.K.-Y.; Shiddiky, M.J. A PCR-free electrochemical method for messenger RNA detection in cancer tissue samples. Biosens. Bioelectron. 2017, 98, 227-233. [CrossRef]

43. Rodrigues, V.C.; Soares, J.C.; Soares, A.C.; Braz, D.C.; Melendez, M.E.; Ribas, L.C.; Scabini, L.F.; Bruno, O.M.; Carvalho, A.L.; Reis, R.M. Electrochemical and optical detection and machine learning applied to images of genosensors for diagnosis of prostate cancer with the biomarker PCA3. Talanta 2021, 222, 121444. [CrossRef]

44. Yang, L.; Kim, T.H.; Cho, H.Y.; Luo, J.; Lee, J.M.; Chueng, S.T.D.; Hou, Y.; Yin, P.T.T.; Han, J.; Kim, J.H. Hybrid Graphene-Gold Nanoparticle-Based Nucleic Acid Conjugates for Cancer-Specific Multimodal Imaging and Combined Therapeutics. Adv. Func. Mater. 2021, 31, 2006918. [CrossRef]

45. Grillone, K.; Riillo, C.; Scionti, F.; Rocca, R.; Tradigo, G.; Guzzi, P.H.; Alcaro, S.; Di Martino, M.T.; Tagliaferri, P.; Tassone, P. Non-coding RNAs in cancer: Platforms and strategies for investigating the genomic "dark matter". J. Exp. Clin. Cancer Res. 2020, 39, 1-19. [CrossRef]

46. Shuai, H.-L.; Huang, K.-J.; Chen, Y.-X.; Fang, L.-X.; Jia, M.-P. Au nanoparticles/hollow molybdenum disulfide microcubes based biosensor for microRNA-21 detection coupled with duplex-specific nuclease and enzyme signal amplification. Biosens. Bioelectron. 2017, 89, 989-997. [CrossRef] [PubMed]

47. Shandilya, R.; Ranjan, S.; Khare, S.; Bhargava, A.; Goryacheva, I.Y.; Mishra, P.K. Point-of-care diagnostics approaches for detection of lung cancer-associated circulating miRNAs. Drug Discov. Today 2021. [CrossRef]

48. Wang, C.; Peng, R.; Zeng, M.; Zhang, Z.; Liu, S.; Jiang, D.; Lu, Y.; Zou, F. An autoregulatory feedback loop of miR-21/VMP1 is responsible for the abnormal expression of miR-21 in colorectal cancer cells. Cell Death Dis. 2020, 11, 1-14. [CrossRef] [PubMed]

49. He, S.; Zhang, G.; Dong, H.; Ma, M.; Sun, Q. miR-203 facilitates tumor growth and metastasis by targeting fibroblast growth factor 2 in breast cancer. Onco Targets Ther. 2016, 9, 6203. [CrossRef]

50. Mohammadi, A.; Mansoori, B.; Duijf, P.H.; Safarzadeh, E.; Tebbi, L.; Najafi, S.; Shokouhi, B.; Sorensen, G.L.; Holmskov, U.; Baradaran, B. Restoration of miR-330 expression suppresses lung cancer cell viability, proliferation, and migration. J. Cell. Physiol. 2021, 236, 273-283. [CrossRef] [PubMed]

51. Mohammadi, S.; Mohammadi, S.; Salimi, A. A 3D hydrogel based on chitosan and carbon dots for sensitive fluorescence detection of microRNA-21 in breast cancer cells. Talanta 2021, 224, 121895. [CrossRef] [PubMed]

52. Zhou, L.; Wang, T.; Bai, Y.; Li, Y.; Qiu, J.; Yu, W.; Zhuo, Y. Dual-amplified strategy for ultrasensitive electrochemical biosensor based on click chemistry-mediated enzyme-assisted target recycling and functionalized fullerene nanoparticles in the detection of microRNA-141. Biosens. Bioelectron. 2020, 150, 111964. [CrossRef] [PubMed]

53. Yang, F.; Yang, F.; Tu, T.-T.; Liao, N.; Chai, Y.-Q.; Yuan, R.; Zhuo, Y. A synergistic promotion strategy remarkably accelerated electrochemiluminescence of $\mathrm{SnO}_{2}$ QDs for MicroRNA detection using 3D DNA walker amplification. Biosens. Bioelectron. 2021, 173, 112820. [CrossRef] [PubMed] 
54. Chang, Y.-F.; Chou, Y.-T.; Cheng, C.-Y.; Hsu, J.-F.; Su, L.-C.; Ho, J.-A.A. Amplification-free Detection of Cytomegalovirus miRNA Using a Modification-free Surface Plasmon Resonance Biosensor. Anal. Chem. 2021. [CrossRef]

55. Zhang, Q.; Wang, F.; Zhang, H.; Zhang, Y.; Liu, M.; Liu, Y. Universal Ti3C2 MXenes based self-standard ratiometric fluorescence resonance energy transfer platform for highly sensitive detection of exosomes. Anal. Chem. 2018, 90, 12737-12744. [CrossRef]

56. Kaur, A.; Dhakal, S. Recent applications of FRET-based multiplexed techniques. Trends Anal. Chem. 2020, 123, 115777. [CrossRef]

57. Pollock, A.J.; Zaver, S.A.; Woodward, J.J. A STING-based biosensor affords broad cyclic dinucleotide detection within single living eukaryotic cells. Nat. Commun. 2020, 11, 1-13. [CrossRef] [PubMed]

58. Melnychuk, N.; Egloff, S.; Runser, A.; Reisch, A.; Klymchenko, A.S. Light-Harvesting Nanoparticle Probes for FRET-Based Detection of Oligonucleotides with Single-Molecule Sensitivity. Angew. Chem. 2020, 132, 6878-6885. [CrossRef]

59. Zhang, X.; Hu, Y.; Yang, X.; Tang, Y.; Han, S.; Kang, A.; Deng, H.; Chi, Y.; Zhu, D.; Lu, Y. FÖrster resonance energy transfer (FRET)-based biosensors for biological applications. Biosens. Bioelectron. 2019, 138, 111314. [CrossRef]

60. Selvin, P.R. The renaissance of fluorescence resonance energy transfer. Nat. Struct. Mol. Biol. 2000, 7, 730-734. [CrossRef] [PubMed]

61. Li, T.; Wang, Z.; Jiang, D.; Wang, H.; Lai, W.-F.; Lv, Y.; Zhai, Y. A FRET biosensor based on MnO2 nanosphere/copper nanocluster complex: From photoluminescence quenching to recovery and magnification. Sens. Actuators B Chem. 2019, 290, 535-543. [CrossRef]

62. Karimi, M.A.; Dadmehr, M.; Hosseini, M.; Korouzhdehi, B.; Oroojalian, F. Sensitive detection of methylated DNA and methyltransferase activity based on the lighting up of FAM-labeled DNA quenched fluorescence by gold nanoparticles. RSC Adv. 2019, 9, 12063-12069. [CrossRef]

63. Tyagi, A.; Chu, K.L.; Abidi, I.H.; Cagang, A.A.; Zhang, Q.; Leung, N.L.; Zhao, E.; Tang, B.Z.; Luo, Z. Single-probe multistate detection of DNA via aggregation-induced emission on a graphene oxide platform. Acta Biomater. 2017, 50, 334-343. [CrossRef]

64. Eftekhari-Sis, B.; Aliabad, M.A.; Karimi, F. Graphene oxide based nano-biosensor for the detection of deletion mutation in exon 19 of EGFR gene, leading to lung cancer. Mater. Lett. 2016, 183, 441-443. [CrossRef]

65. Peng, X.; Zhang, Y.; Lu, D.; Guo, Y.; Guo, S. Ultrathin Ti3C2 nanosheets based "off-on" fluorescent nanoprobe for rapid and sensitive detection of HPV infection. Sens. Actuators B Chem. 2019, 286, 222-229. [CrossRef]

66. Severi, C.; Melnychuk, N.; Klymchenko, A.S. Smartphone-assisted detection of nucleic acids by light-harvesting FRET-based nanoprobe. Biosens. Bioelectron. 2020, 168, 112515. [CrossRef] [PubMed]

67. Wang, S.; Wei, S.; Wang, S.; Zhu, X.; Lei, C.; Huang, Y.; Nie, Z.; Yao, S. Chimeric DNA-functionalized titanium carbide MXenes for simultaneous mapping of dual cancer biomarkers in living cells. Anal. Chem. 2018, 91, 1651-1658. [CrossRef] [PubMed]

68. Oudeng, G.; Au, M.; Shi, J.; Wen, C.; Yang, M. One-step in situ detection of miRNA-21 expression in single cancer cells based on biofunctionalized MoS2 nanosheets. ACS Appl. Mater. Interfaces 2018, 10, 350-360. [CrossRef]

69. Afzalinia, A.; Mirzaee, M. Ultrasensitive fluorescent miRNA biosensor based on a "sandwich" oligonucleotide hybridization and fluorescence resonance energy transfer process using an Ln (III)-MOF and Ag nanoparticles for early cancer diagnosis: Application of central composite design. ACS Appl. Mater. Interfaces 2020, 12, 16076-16087. [CrossRef] [PubMed]

70. Chu, Y.; Gao, Y.; Tang, W.; Qiang, L.; Han, Y.; Gao, J.; Zhang, Y.; Liu, H.; Han, L. Attomolar-Level Ultrasensitive and Multiplex microRNA Detection Enabled by a Nanomaterial Locally Assembled Microfluidic Biochip for Cancer Diagnosis. Anal. Chem. 2021, 93, 5129-5136. [CrossRef]

71. Sekhon, S.S.; Kaur, P.; Kim, Y.-H.; Sekhon, S.S. 2D graphene oxide-aptamer conjugate materials for cancer diagnosis. npj 2D Mater. Appl. 2021, 5, 1-19. [CrossRef]

72. Yadav, V.; Roy, S.; Singh, P.; Khan, Z.; Jaiswal, A. 2D MoS2-based nanomaterials for therapeutic, bioimaging, and biosensing applications. Small 2019, 15, 1803706. [CrossRef] [PubMed]

73. Dhenadhayalan, N.; Yadav, K.; Sriram, M.I.; Lee, H.-L.; Lin, K.-C. Ultra-sensitive DNA sensing of a prostate-specific antigen based on 2D nanosheets in live cells. Nanoscale 2017, 9, 12087-12095. [CrossRef] [PubMed]

74. Badshah, M.A.; Koh, N.Y.; Zia, A.W.; Abbas, N.; Zahra, Z.; Saleem, M.W. Recent Developments in Plasmonic Nanostructures for Metal Enhanced Fluorescence-Based Biosensing. Nanomaterials 2020, 10, 1749. [CrossRef] [PubMed]

75. Geddes, C.D. Metal-enhanced fluorescence. Phys. Chem. Chem. Phys. PCCP 2013, 15, 19537. [CrossRef]

76. Bauch, M.; Toma, K.; Toma, M.; Zhang, Q.; Dostalek, J. Plasmon-Enhanced Fluorescence Biosensors: A Review. Plasmonics 2014, 9 , 781-799. [CrossRef] [PubMed]

77. Yan, Y.; Meng, L.; Zhang, W.; Zheng, Y.; Wang, S.; Ren, B.; Yang, Z.; Yan, X. High-throughput single-particle analysis of metalenhanced fluorescence in free solution using Ag@ SiO2 core-shell nanoparticles. ACS Sens. 2017, 2, 1369-1376. [CrossRef] [PubMed]

78. Xu, D.D.; Liu, C.; Li, C.Y.; Song, C.Y.; Kang, Y.F.; Qi, C.B.; Lin, Y.; Pang, D.W.; Tang, H.W. Dual Amplification Fluorescence Assay for Alpha Fetal Protein Utilizing Immunohybridization Chain Reaction and Metal-Enhanced Fluorescence of Carbon Nanodots. ACS Appl. Mater. Interfaces 2017, 9, 37606-37614. [CrossRef]

79. Zhou, R.; Sun, S.; Li, C.; Wu, L.; Hou, X.; Wu, P. Enriching Mn-Doped ZnSe Quantum Dots onto Mesoporous Silica Nanoparticles for Enhanced Fluorescence/Magnetic Resonance Imaging Dual-Modal Bio-Imaging. ACS Appl. Mater. Interfaces 2018, 10, 34060-34067. [CrossRef]

80. Manurung, R.V.; Wu, C.T.; Roy, P.K.; Chattopadhyay, S. A plasmon-tuned 'gold sandwich'for metal enhanced fluorescence in silica coated NaYF 4: Yb, Er upconversion nanoparticles. RSC Adv. 2016, 6, 87088-87095. [CrossRef] 
81. Choi, J.H.; Choi, J.W. Metal-Enhanced Fluorescence by Bifunctional Au Nanoparticles for Highly Sensitive and Simple Detection of Proteolytic Enzyme. Nano Lett. 2020, 20, 7100-7107. [CrossRef] [PubMed]

82. Miranda, B.; Chu, K.Y.; Maffettone, P.L.; Shen, A.Q.; Funari, R. Metal-Enhanced Fluorescence Immunosensor Based on Plasmonic Arrays of Gold Nanoislands on an Etched Glass Substrate. ACS Appl. Nano Mater. 2020, 3, 10470-10478. [CrossRef]

83. Sabanayagam, C.R.; Lakowicz, J.R. Increasing the sensitivity of DNA microarrays by metal-enhanced fluorescence using surfacebound silver nanoparticles. Nucleic Acids Res. 2007, 35, e13. [CrossRef]

84. Ji, X.; Xiao, C.; Lau, W.F.; Li, J.; Fu, J. Metal enhanced fluorescence improved protein and DNA detection by zigzag Ag nanorod arrays. Biosens. Bioelectron. 2016, 82, 240-247. [CrossRef] [PubMed]

85. Mei, Z.; Tang, L. Surface-Plasmon-Coupled Fluorescence Enhancement Based on Ordered Gold Nanorod Array Biochip for Ultrasensitive DNA Analysis. Anal. Chem. 2017, 89, 633-639. [CrossRef] [PubMed]

86. Badshah, M.A.; Ju, J.; Lu, X.; Abbas, N.; Kim, S.M. Enhancing the sensitivity of DNA microarrays by metal-enhanced fluorescence using vertical nanorod structures. Sens. Actuator B Chem. 2018, 274, 451-457. [CrossRef]

87. Tran, N.H.T.; Trinh, K.T.L.; Lee, J.H.; Yoon, W.J.; Ju, H. Reproducible Enhancement of Fluorescence by Bimetal Mediated Surface Plasmon Coupled Emission for Highly Sensitive Quantitative Diagnosis of Double-Stranded DNA. Small 2018, 14, 1801385. [CrossRef]

88. Zhou, Z.; Li, T.; Huang, H.; Chen, Y.; Liu, F.; Huang, C.; Li, N. A dual amplification strategy for DNA detection combining bio-barcode assay and metal-enhanced fluorescence modality. Chem. Commun. (Camb.) 2014, 50, 13373-13376. [CrossRef] [PubMed]

89. Gu, X.F.; Wu, Y.S.; Zhang, L.Z.; Liu, Y.C.; Li, Y.; Yan, Y.L.; Wu, D.C. Hybrid magnetic nanoparticle/nanogold clusters and their distance-dependent metal-enhanced fluorescence effect via DNA hybridization. Nanoscale 2014, 6, 8681-8693. [CrossRef]

90. Wu, S.; Li, C.; Shi, H.; Huang, Y.; Li, G. Design of metal-organic framework-based nanoprobes for multicolor detection of DNA targets with improved sensitivity. Anal. Chem. 2018, 90, 9929-9935. [CrossRef]

91. Zhu, Z.J.; Yuan, P.Y.; Li, S.; Garai, M.; Hong, M.H.; Xu, Q.H. Plasmon-Enhanced Fluorescence in Coupled Nanostructures and Applications in DNA Detection. Acs Appl. Bio Mater. 2018, 1, 118-124. [CrossRef]

92. Choi, J.H.; Lim, J.; Shin, M.; Paek, S.H.; Choi, J.W. CRISPR-Cas12a-Based Nucleic Acid Amplification-Free DNA Biosensor via Au Nanoparticle-Assisted Metal-Enhanced Fluorescence and Colorimetric Analysis. Nano Lett. 2021, 21, 693-699. [CrossRef]

93. Aslan, K.; Huang, J.; Wilson, G.M.; Geddes, C.D. Metal-enhanced fluorescence-based RNA sensing. J. Am. Chem. Soc. 2006, 128, 4206-4207. [CrossRef] [PubMed]

94. Liang, L.; Lan, F.; Yin, X.; Ge, S.; Yu, J.; Yan, M. Metal-enhanced fluorescence/visual bimodal platform for multiplexed ultrasensitive detection of microRNA with reusable paper analytical devices. Biosens. Bioelectron. 2017, 95, 181-188. [CrossRef] [PubMed]

95. Wang, Z.L.; Zong, S.F.; Wang, Z.Y.; Wu, L.; Chen, P.; Yun, B.F.; Cui, Y.P. Microfluidic chip based micro RNA detection through the combination of fluorescence and surface enhanced Raman scattering techniques. Nanotechnology 2017, 28, 105501. [CrossRef]

96. Masterson, A.N.; Liyanage, T.; Berman, C.; Kaimakliotis, H.; Johnson, M.; Sardar, R. A novel liquid biopsy-based approach for highly specific cancer diagnostics: Mitigating false responses in assaying patient plasma-derived circulating microRNAs through combined SERS and plasmon-enhanced fluorescence analyses. Analyst 2020, 145, 4173-4180. [CrossRef] [PubMed]

97. Lu, L.Y.; Tu, D.T.; Liu, Y.; Zhou, S.Y.; Zheng, W.; Chen, X.Y. Ultrasensitive detection of cancer biomarker microRNA by amplification of fluorescence of lanthanide nanoprobes. Nano Res. 2018, 11, 264-273. [CrossRef]

98. Lee, J.H.; Choi, J.H.; Chueng, S.D.; Pongkulapa, T.; Yang, L.; Cho, H.Y.; Choi, J.W.; Lee, K.B. Nondestructive Characterization of Stem Cell Neurogenesis by a Magneto-Plasmonic Nanomaterial-Based Exosomal miRNA Detection. ACS Nano 2019, 13, 8793-8803. [CrossRef]

99. Xu, J.; Zhao, J.; Zhang, R. Four microRNAs Signature for Survival Prognosis in Colon Cancer using TCGA Data. Sci. Rep. 2016, 6, 1-8. [CrossRef] [PubMed]

100. Wu, Q.; Yu, L.; Lin, X.; Zheng, Q.; Zhang, S.; Chen, D.; Pan, X.; Huang, Y. Combination of Serum miRNAs with Serum Exosomal miRNAs in Early Diagnosis for Non-Small-Cell Lung Cancer. Cancer Manag. Res. 2020, 12, 485-495. [CrossRef]

101. Song, C.; Chen, W.H.; Kuang, J.Y.; Yao, Y.; Tang, S.; Zhao, Z.; Guo, X.J.; Shen, W.; Lee, H.K. Recent advances in the detection of multiple microRNAs. Trends Anal. Chem. 2021, 139, 116269. [CrossRef] 